\title{
Liquidity constraints, spillovers, and entrepreneurship: evidence from a cash transfer program
}

\author{
Rafael P. Ribas $\mathbb{1}$
}

Accepted: 30 April 2019/Published online: 21 May 2019

(C) The Author(s) 2019

\begin{abstract}
This paper exploits a liquidity shock from a welfare program in Brazil to investigate the role of financial constraints, in opposition to general equilibrium mechanisms, in explaining entrepreneurship. Previous research focuses exclusively on how liquidity changes recipients' behavior through direct effects on reducing constraints. However, liquidity shocks may also produce spillovers from recipients to others and thereby indirectly affect entrepreneurial decisions. This paper presents a method for decomposing the liquidity shock into direct effects associated with relieving individual constraints, and indirect effects associated with spillovers to other individuals. Results suggest that the program, which assists 20 percent of Brazilian households, increased the number of small entrepreneurs by 10 percent. However, this increase is entirely driven by the indirect effect. Further tests suggest that this effect is associated with an increase in private transfers between households. Thus, entrepreneurship tends to
\end{abstract}

Electronic supplementary material The online version of this article (https://doi.org/10.1007/s11187-019-00178-1) contains supplementary material, which is available to authorized users.

\section{R. P. Ribas ( $\triangle)$}

Amsterdam Business School, University of Amsterdam, Plantage Muidergracht 12, 1018 TV Amsterdam,

Netherlands

e-mail: r.perezribas@uva.nl respond more to the interaction between households than to financial constraints.

Keywords Entrepreneurship · Financial constraint · Cash transfers · Informality · Indirect effect · Private transfers

JEL Classification $\mathrm{C} 21 \cdot \mathrm{H} 31 \cdot \mathrm{I} 38 \cdot \mathrm{J} 24 \cdot \mathrm{R} 28$. R51 - L26

\section{Introduction}

There has been a long debate over whether insufficient liquidity hinders individuals from starting their own business. In general, the literature suggests that financial constraints tend to inhibit those with insufficient funds at their disposal. ${ }^{1}$ Under imperfect financial markets, individual savings could be the way

\footnotetext{
${ }^{1}$ A non-exhaustive list of papers includes Evans and Jovanovic (1989), Evans and Leighton (1989), Holtz-Eakin et al. (1994), Lindh and Ohlsson (1996), Blanchflower and Oswald (1998), Blanchflower et al. (2001), Lindh and Ohlsson (1998), Fairlie (1999), Johansson (2000), Taylor (2001), Hurst and Lusardi (2004), Holtz-Eakin and Rosen (2005), Zissimopoulos and Karoly (2007), Nykvist (2008), and Fairlie and Krashinsky (2012).
} 
that small entrepreneurs cope with start-up costs and investment risks (Ghatak et al. 2001), which yet represent a large sacrifice for poor individuals (Buera 2009). ${ }^{2}$ On the other hand, the latent entrepreneurial activity could also be explained by the lack of investment opportunities in underdeveloped areas (Sadoulet et al. 2001; Davies and Davey 2008). Also, informal financial arrangements, such as interpersonal lending (Tsai 2004; Fafchamps and Gubert 2007; Schechter and Yuskavage 2012) and mutual insurance (Murgai et al. 2002; Fafchamps and Lund 2003), are often reported as a form of households making investments and sharing idiosyncratic risks.

This paper explores the importance of both financial constraints and general equilibrium mechanisms by estimating the impact of a liquidity shock on the decision to be an entrepreneur in urban areas. Unlike other interventions (e.g., Karlan and Zinman 2010; Blattman et al. 2014), liquidity is not delivered uniquely to entrepreneurs. The studied intervention is a large-scale conditional cash transfer (CCT) program in Brazil, called Bolsa Família. This program offers a small but steady income to poor households that are committed to send their children to school and have regular health check-ups. However, it has absolutely no rule regarding business investment, adult labor supply or repayment. Thus, its benefit is viewed as a simple liquidity shock on the beneficiaries' budget.

In addition to the direct effect on CCT recipients' behavior, we also attempt to identify the indirect effect that this program has on local economies, without necessarily assuming an economic multiplier. If potential entrepreneurs face financial constraints, the individual liquidity shock should change recipients' occupational choice because it gives them a chance to invest more without borrowing and to protect their earnings without insurance (Rosenzweig and Wolpin 1993; Bianchi and Bobba 2013). However, entrepreneurs may also rely on family and friends when they decide to start a business (Persson and Lee 2016). In this case, their decision is not as affected by their cash benefit as it is by the disposable income in their network. By raising the income of family and friends, entrepreneurs will be more willing to take risks. Therefore, while the size of the direct effect reveals the role of financial

\footnotetext{
${ }^{2}$ See also Banerjee and Newman (1993), Galor and Zeira (1993), Aghion and Bolton (1997), and Banerjee and Duflo (2005).
}

constraints, the indirect effect reveals the role of the opportunity cost in an existent network.

Some studies have already attempted to assess the indirect effect that cash transfers have on the whole community. ${ }^{3}$ For instance, Angelucci and De Giorgi (2009) find that non-poor households are also affected by PROGRESA/Opportunidades in rural villages in Mexico. They suggest that these households increase food consumption by receiving private transfers from program participants and reducing their precautionary savings. In another study, Bandiera et al. (2009) assess the effect of asset transfers in Bangladesh. They show that this program has indirect effects on time allocation in risk-sharing networks and on durable consumption in family networks.

Although formal entrepreneurship is a rare event among households, the estimation of direct and indirect effects is possible because Bolsa Família is a widespread program that was gradually introduced in many different areas in Brazil. The main identification issue is that the individual assignment is not random. Yet we demonstrate that this is not a concern as long as the selection of participants is not related to the overall amount of transfers received in the entire municipality. Namely, the eligibility of households only affects the local distribution of benefits.

In the case of Bolsa Familia, the total number of transfers per municipality is considered given because, from 2003 to 2007, its growth was strongly driven by municipal quotas (Bastagli 2008; Barros et al. 2008). These quotas were defined by the estimated number of poor households in 2001. Even though this number is related to actual poverty, it is also subject to error. Moreover, the poverty headcount in some municipalities changed from 2001 to 2003, before the quotas were actually applied. Controlling for actual poverty, the municipal quotas are used as an instrument to verify whether the local growth of the program is endogenous.

Instead of comparing participants and nonparticipants in the same municipality, the overall effect is estimated simply by comparing municipalities over time. The direct and indirect effects, however, are

\footnotetext{
${ }^{3}$ See Bobonis and Finan (2009), Lalive and Cattaneo (2009), Angelucci et al. (2009, 2010), and Bobba and Gignoux (2019). See also Crépon et al. (2013), and Beegle et al. (2017) on the indirect effect of labor market policies, and Miguel and Kremer (2004) and Kremer and Miguel (2007) on the spillovers of health programs.
} 
calculated by a two-step procedure. First, we estimate the indirect effect of program coverage on nonparticipants and test whether this effect is linear and hence equal to the indirect impact on participants. As long as this hypothesis is not rejected, estimating the direct response does not require individual-level randomization of the treatment, unlike Duflo and Saez (2003). The estimated indirect effect is used to calculate the selection bias of the estimated direct effect. This empirical strategy allows me to ignore selection within municipalities and, based on a verifiable assumption, decompose the overall effect of the program on eligible individuals.

The findings suggest that the proportion of entrepreneurs among less-educated men has grown by 10 percent because of the Bolsa Familia program, which had covered about 20 percent of households by 2006. At first glance, this finding supports the hypothesis that a small amount of secure cash can have a considerable impact on occupational choice. However, the direct and indirect components go in opposite directions. While the rise in entrepreneurial activity is entirely driven by spillovers, the direct response of participants reduces the overall effect by 40 percent. This drawback seems to be induced by households' risk of losing the benefit when their earned income increases. ${ }^{4}$ Informal self-employment, on the other hand, increases among recipients, which is consistent with the view of self-employment as a way to manipulate taxable income (Saez 2010; Chetty et al. 2013). We also find that the positive spillover happens exclusively in small towns. In dense cities, the negative direct effect on entrepreneurial activity is significantly larger than the indirect effect.

The contribution of this study is twofold. First, it suggests individual liquidity constraints are not as important as aggregate constraints in hindering entrepreneurship among the poor. Studies that find a relationship between liquidity shocks and entrepreneurship (e.g., Gertler et al. 2012; Bianchi and Bobba 2013; Bandiera et al. 2017) often exploit interventions that are

\footnotetext{
${ }^{4}$ This finding is consistent with the direct effect of Bolsa Família on informality presented by de Brauw et al. (2015), but it challenges previous studies that find no significant effects on labor supply (Oliveira et al. 2007; Tavares 2008; Foguel and Barros 2010; Ferro et al. 2010; Teixeira 2010).
}

clustered at the village level. In this case, the estimated effect should be viewed as the sum of individual and local responses (Hudgens and Halloran 2008). What is usually interpreted as an individual shock, which lessens liquidity constraints, may actually be a locally aggregate shock, which affects the entire village. This misconception explains, for instance, why microcredit programs usually have low take-up, crowd out informal lending, and are not so effective in terms of business creation (Banerjee et al. 2015b).

The second main contribution of this study relates to the impact of cash transfer programs on incomegenerating activities. Although these programs are only intended to alleviate poverty in the short run and improve children's opportunities in the long run, they are also found to encourage the creation of small enterprises. Nevertheless, since this positive impact is not on the individual but on the economy, it tends to be more important for less dynamic areas (i.e., small towns). Even though the poor in large cities are also entitled to the benefit, the negative response from beneficiaries outweighs the potential spillovers.

The remainder of the paper is organized as follows. Section 2 describes the main features of Bolsa Família, including its targeting mechanism based on a poverty map, and the panel data used in the empirical analysis. Section 3 details the identification strategy for the overall effect, as well as for the indirect and direct effects. Section 4 presents the main empirical findings, whereas Section 5 presents tests for potential mechanisms, including increasing private transfers, demand shocks, and confounding factors. Section 6 concludes the paper.

\section{Program and data description}

In this section, we outline the main characteristics of the Bolsa Família program, as well as the panel data used in the analysis. Most important, we describe how the growth of this program is closely related to the municipal quotas, making it less likely to be driven by economic opportunities and pork barrel politics at the local level. Furthermore, we explain how the National Household Survey (Pesquisa Nacional por Amostra de Domicílios, PNAD) may be used in a panel setting even though it is a rotating cross-sectional survey. 


\subsection{The Bolsa Família program}

In Brazil, the first Conditional Cash Transfer (CCT) programs managed by the federal government were created in 2001. The first, called Bolsa Escola, was conditional on poor children between six and 15 years being enrolled in and regularly attending primary school. Another program, called Bolsa Alimentação, was intended to improve the health care and nutrition of children up to six years and pregnant women. In 2003, the government created the Bolsa Família program, merging all these previous programs into one with the standardization of eligibility criteria, benefit values, information systems, and executing agency. The program also brought in a gradual expansion of CCTs in Brazil, from 5.1 million families in December 2002 to 11.1 million families in October 2006. The target number of 11 million was calculated based on the estimated number of poor families according to the PNAD in 2001.

In 2006 , extremely poor families with no children, whose per capita monthly income was below US\$38, and poor families with children up to 15 years old or pregnant women, whose per capita monthly income was below US\$76, were eligible for the program. The monthly benefit was composed of two parts: US\$38 for extremely poor families regardless of the number of children, and US\$11 per child, up to three children, for poor families. ${ }^{5}$ Like Bolsa Escola and Bolsa Alimentação, this benefit requires household commitment in terms of children's education and health care. However, if the family is registered as extremely poor with no children, the US\$38 transfer is considered unconditional.

Families that receive the benefit can be dropped from the program not only in case of not complying with the conditionalities, but also when their per capita income becomes greater than the eligibility cutoff point. During the period covered by this study, whenever it was found that the household per capita income had been above the eligibility threshold, the family would be excluded from the payroll. Moreover, families are required to update their records on the single registry of social policies (Cadastro Único) at least once every two years. As for monitoring of the

\footnotetext{
${ }^{5}$ In 2004, the extreme poverty line for the program was US $\$ 33$, the poverty line was US\$66, and the value of the benefit per child was US\$10.
}

income information, the federal government regularly matches beneficiaries' records with other government databases, such as workers' salaries from the Ministry of Labor and Employment and the value of pensions and contributions from the Ministry of Social Security.

For instance, the government found that 622,476 participant households had earnings above the eligibility cutoff between October 2008 and February 2009. From this total, 451,021 households had their benefit canceled. From cross-checking its databases, the government had canceled the benefit of more than 1 million households between 2004 and 2008, which represents about $40 \%$ of the total number of withdrawals.

\subsection{Program's targeting}

To identify poor families around the country, the municipalities are free to decide about the priority areas and how the registration process takes place. However, they do receive some guidelines, in the form of quotas on the number of benefits. This cap on benefits is intended to prevent local governments from spending the federal transfers irresponsibly and using them for electoral purposes. Hence, each municipality has a limited number of benefits to be distributed, which is given by the estimated number of poor households.

The municipal quotas were initially defined by a poverty map made by the National Statistics Office (Instituto Brasileiro de Geografia and Estatística, IBGE). This map was made using both the 2001 PNAD and the 2000 Demographic Census and was used for the quotas until 2006, when it started being updated annually. In other words, given the target of 11 million families in the whole country, the 2001 poverty map guided how the program should have gradually grown across municipalities from 2003 to 2006.

Figure 1 confirms that the number of benefits per municipality depended heavily on the municipal quotas. In 2004, when the program was still expanding and had not reached the cap in most municipalities, the quotas explain $78 \%$ of the municipal coverage. In 2006, when the program reached its target, the relationship is even stronger and close to the 45-degree line. Almost $92 \%$ of the distribution of transfers across municipalities is explained by the target coverage, measured five years earlier. In Section 4.1, we show 


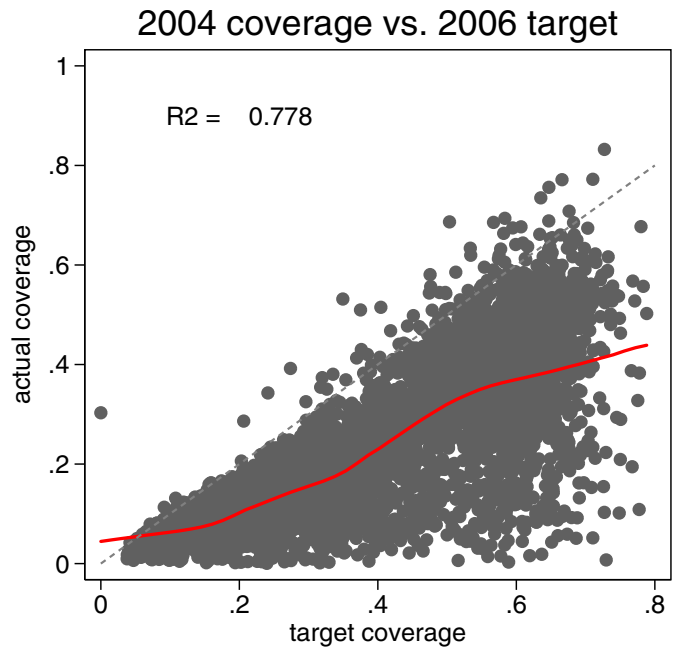

Fig. 1 Relationship between program coverage and municipal quotas. Program coverage is measured by the proportion of households participating in the program. Target coverage is the

how the quotas still explain the actual coverage, after controlling for individual characteristics and poverty level.

\subsection{Data}

\subsubsection{Panel sample}

The main data source is PNAD. This survey, which collects a broad set of information on demographic and socio-economic characteristics of households, included a special questionnaire on cash transfer programs in 2004 and 2006. This questionnaire asked whether any member of the household was a beneficiary of each cash transfer program that was in place at the time of the survey. Henceforth, we consider as Bolsa Família all previous programs that had a similar goal and design (e.g., Bolsa Alimentação, Cartão Alimentação, Bolsa Escola, and PETI).

In addition to these two survey years, we use the 2001 PNAD as a baseline. Although the Bolsa Família program had not taken place yet and the other cash transfer programs were not a significant size before 2003, we identify those households receiving cash transfers using the typical-value method developed by Foguel and Barros (2010). This method basically matches parts of household income, under the entry of "other incomes," with typical values transferred by

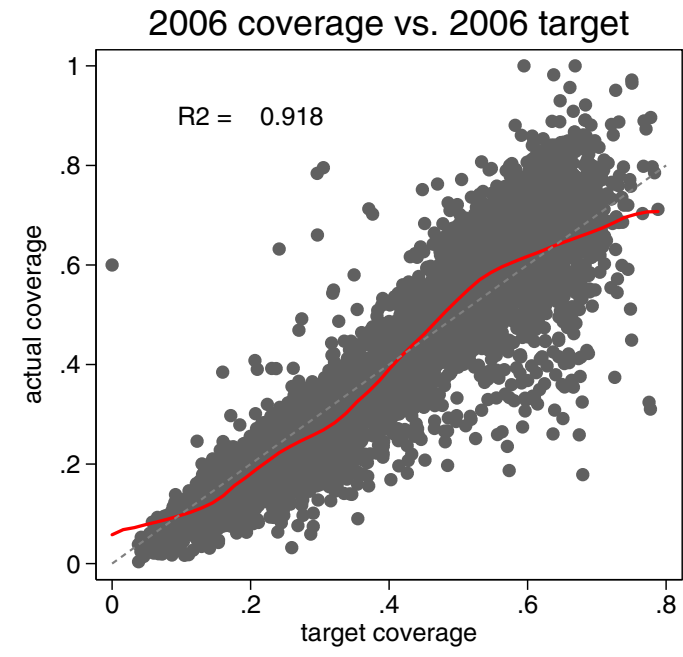

municipal quota divided by the number of households. Each point represents a municipality. Regressions are weighted by the number of households per municipality

each program. The 2002 PNAD is also used to estimate local poverty and changes in entrepreneurship before 2003.

PNAD is a cross-sectional survey, so it does not interview the same household twice. Thus, we cannot construct a panel of households or even individuals. However, for each decade-i.e., the period between two Demographic Censuses-the replacement of households on its sample occurs within the same census tracts. ${ }^{6}$ Although they are not georeferenced because the key variable is encrypted, we are able to identify the same census tracts and municipalities through the years. This sampling scheme permits the estimation of a fixed-effect model, described later in this paper.

\subsubsection{Defining entrepreneurship}

Given the common characteristics of entrepreneurs, the sample is restricted to men who are between 25 and 45 years old and reside in urban areas. Indeed, empirical studies show that men are more likely than

\footnotetext{
$\overline{{ }^{6} \mathrm{~A} \text { census tract }}$ is a neighborhood that has between 250 and 350 households in urban areas, 150 and 250 households in suburban areas, 51 and 350 households in informal settlement areas, 51 and 250 households in rural areas, and at least 20 households in indigenous areas (IBGE 2000).
} 
women to pursue entrepreneurial activity (Blanchflower 2000; Karlan and Zinman 2010). They also show that the probability of being an entrepreneur is increasing with age, but the probability of starting a new business is decreasing after 30 years of age (Ardagna and Lusardi 2010).

We also exclude public servants, people with higher education, and employers with more than five employees from the sample. Even though $6 \%$ of public servants were participating in the program in 2006, they are less likely to change occupation due to the stability of their job. The last two groups were excluded because only $1 \%$ of them were receiving the benefit in 2006 , so they are practically ineligible for the transfer. In addition, businesses with more than five employees might already be well established, so they are less sensitive at the extensive margin. ${ }^{7}$

Following Blanchflower (2000) and Blanchflower et al. (2001), we classify as entrepreneurs those who are either self-employed or small-business owners. For Brazil in particular, small entrepreneurs are those who are either self-employed, excluding domestic workers, or business owners with at most five employees (Fajnzylber et al. 2011; Monteiro and Assunção 2012). ${ }^{8}$ However, to distinguish between entrepreneurial activity and informality, the definition also requires that they either perform a highskilled job or contribute to social security. Namely, entrepreneurs are more likely to pay taxes and are less vulnerable than informal workers in general (La Porta and Shleifer 2014). Furthermore, the government cannot track earnings of workers in the informal sector, whereas entrepreneurs have their earnings partially revealed in the government records.

For the sample of prime-age men, we construct the following variables based on their main occupation: (1) entrepreneur, equal to one if self-employed in professional or technical occupation (e.g., electrical technician, computer programmers, and visual artists), self-employed in any other occupation and

\footnotetext{
${ }^{7}$ The exclusion of these employers reduces the sample by $1 \%$, with no implication for the results.

${ }^{8}$ In 2008, the Brazilian Government officially introduced the concept of micro-entrepreneur (MEI) in the legislation. To be classified as MEI, the entrepreneur cannot employ more than one worker, who must receive the minimum wage.
}

also contributing to social security, employer with more than two employees, or small employer contributing to social security, and zero otherwise; (2) formal employee, equal to one if employed with documentation or contributing to social security; (3) informal employee, equal to one if employed without documentation and not contributing to social security; (4) informal self-employed, equal to one if self-employed in low-skilled occupation (not requiring job-specific training) and not contributing to social security; (5) jobless, equal to one if not having a remunerated occupation, including unemployed and inactive adults.

Based on these categories, entrepreneurs earn on average $77 \%$ more per hour worked than the informal self-employed, and $45 \%$ more than formal employees. These earnings differentials are also identified at any quantile, confirming that entrepreneurship is more rewarding than other types of occupation (see Fig. 4 in the Appendix.

\subsubsection{Municipal quotas and program coverage}

The municipal quotas, as well as the number of benefits per municipality, are obtained from the Ministry of Social Development and Fight Against Hunger (MDS). To calculate the target and actual coverage, these numbers are divided by the number of households per municipality in 2000, according to the Demographic Census. The match between MDS data and PNAD is possible only for large cities, which can be identified in PNAD based on their size, metropoli$\tan$ status and state. These cities account for $51 \%$ of the final sample. The other half is matched through clusters of municipalities, also defined by population size, metropolitan status and state. Out of 788 municipalities sampled by PNAD in 27 states, we are able to create 178 clusters.

To give more variability within those clusters, we predict the target and actual coverage per municipality as follows. First, we calculate the program coverage in 2001, 2004, and 2006 and the poverty headcount in 2001 per municipality using PNAD. Then, we take the difference between these variables, $\bar{d}_{v c}$, and the official rates from MDS, $\tilde{d}_{c}$. While the rates from MDS are more accurate but have less variance, the rates from PNAD are noisier but have more variance. Then, the difference is estimated as a function of the official 
Table 1 Descriptive statistics

\begin{tabular}{|c|c|c|c|c|c|c|}
\hline & \multicolumn{2}{|l|}{2001} & \multicolumn{2}{|l|}{2004} & \multicolumn{2}{|l|}{2006} \\
\hline & Mean & Std. Dev. & Mean & Std. Dev. & Mean & Std. Dev. \\
\hline \multicolumn{7}{|l|}{ Outcomes } \\
\hline Entrepreneur & 0.069 & 0.254 & 0.068 & 0.252 & 0.072 & 0.258 \\
\hline Entrepreneur-service & 0.040 & 0.197 & 0.026 & 0.160 & 0.028 & 0.165 \\
\hline Entrepreneur-sales & 0.022 & 0.146 & 0.033 & 0.177 & 0.033 & 0.178 \\
\hline Entrepreneur-manufacturing & 0.018 & 0.131 & 0.019 & 0.138 & 0.021 & 0.143 \\
\hline Formal employee & 0.431 & 0.495 & 0.461 & 0.499 & 0.482 & 0.500 \\
\hline Informal employee & 0.152 & 0.359 & 0.147 & 0.354 & 0.140 & 0.347 \\
\hline Informal self-employed & 0.206 & 0.405 & 0.192 & 0.394 & 0.177 & 0.381 \\
\hline Jobless & 0.141 & 0.348 & 0.131 & 0.337 & 0.130 & 0.336 \\
\hline Receiving private transfer & 0.043 & 0.203 & 0.068 & 0.252 & 0.077 & 0.267 \\
\hline \multicolumn{7}{|l|}{ Individual variables } \\
\hline Age & 34.3 & 6.0 & 34.3 & 6.1 & 34.3 & 6.1 \\
\hline White & 0.523 & 0.499 & 0.500 & 0.500 & 0.475 & 0.499 \\
\hline Black & 0.072 & 0.258 & 0.075 & 0.263 & 0.090 & 0.287 \\
\hline Married & 0.725 & 0.446 & 0.705 & 0.456 & 0.689 & 0.463 \\
\hline Elementary education & 0.788 & 0.409 & 0.816 & 0.387 & 0.838 & 0.368 \\
\hline Primary education & 0.445 & 0.497 & 0.508 & 0.500 & 0.545 & 0.498 \\
\hline High school & 0.247 & 0.431 & 0.304 & 0.460 & 0.347 & 0.476 \\
\hline Number of kids & 1.380 & 1.280 & 1.280 & 1.240 & 1.210 & 1.200 \\
\hline Number of elderly & 0.193 & 0.493 & 0.201 & 0.501 & 0.209 & 0.510 \\
\hline Migrant-last 5 years & 0.057 & 0.231 & 0.114 & 0.318 & 0.116 & 0.321 \\
\hline \multicolumn{7}{|l|}{ Municipality variables } \\
\hline Program coverage & 0.047 & 0.088 & 0.156 & 0.109 & 0.201 & 0.141 \\
\hline Target coverage & & & & & 0.270 & 0.163 \\
\hline Poverty headcount in 2002 & & & & & 0.254 & 0.176 \\
\hline Poverty headcount & 0.257 & 0.175 & 0.248 & 0.169 & 0.192 & 0.147 \\
\hline $\log$ of population & 12.9 & 1.38 & 13.0 & 1.37 & 13.0 & 1.37 \\
\hline log of population density & 5.44 & 2.37 & 5.42 & 2.38 & 5.41 & 2.38 \\
\hline Elementary enrollment rate & 0.929 & 0.065 & 0.939 & 0.060 & 0.952 & 0.049 \\
\hline Primary enrollment rate & 0.726 & 0.161 & 0.776 & 0.131 & 0.795 & 0.123 \\
\hline High school enrollment rate & 0.425 & 0.182 & 0.505 & 0.188 & 0.524 & 0.170 \\
\hline Child mortality & 12.7 & 21.3 & 11.0 & 22.2 & 9.8 & 17.2 \\
\hline Coverage of sewer system & 0.484 & 0.354 & 0.514 & 0.363 & 0.514 & 0.357 \\
\hline Prop. of house owners & 0.693 & 0.107 & 0.699 & 0.103 & 0.695 & 0.103 \\
\hline Number of observations & 41,663 & & 43,105 & & 44,802 & \\
\hline
\end{tabular}

rate, population size, $\operatorname{pop}_{v}$, number of municipalities in the cluster, $n_{c}$, and all pairwise interactions:

$$
\begin{array}{r}
\left(\bar{d}_{v c}-\tilde{d}_{c}\right)=\psi_{0}+\psi_{1} \tilde{d}_{c}+\psi_{2} \text { pop }_{v}+\psi_{3} n_{c} \\
+\psi_{4} \tilde{d}_{c} p o p_{v}+\psi_{5} \tilde{d}_{c} n_{c}+\varepsilon_{v c}
\end{array}
$$

Finally, the predicted rate is equal to the official rate plus the predicted difference:

$$
\hat{d}_{v c}= \begin{cases}\tilde{d}_{c} & \text { if } n_{c}=1 \\ \tilde{d}_{c}+\hat{\psi}_{0}+\hat{\psi}_{1} \tilde{d}_{c}+\hat{\psi}_{2} p o p_{v} & \\ +\hat{\psi}_{3} n_{c}+\hat{\psi}_{4} \tilde{d}_{c} p o p_{v}+\hat{\psi}_{5} \tilde{d}_{c} n_{c} & \text { if } n_{c}>1\end{cases}
$$

\subsubsection{Descriptive statistics}

Table 1 shows the descriptive statistics of outcomes and control variables. From 2001 to 2006, the entrepreneurship rate increased by 0.3 percentage points (p.p.), from 6.9 to $7.2 \%$. Moreover, the type of business changed mostly in 2004, with more entrepreneurs in sales and fewer in services.

Although the overall level has changed slightly, several factors might have affected the decision of loweducated workers to be an entrepreneur. For instance, with better opportunities in the formal sector, some 
entrepreneurs might have switched to the position of documented employee, while informally employed workers might have perceived opportunities to open their own businesses. Indeed, participation in the formal sector increased by 5 p.p. in this period, whereas the proportion of informal workers (employed or selfemployed) decreased by 4 p.p.

With the creation of Bolsa Família in 2003, the percentage of individuals receiving cash transfers (program coverage) went from $4.7 \%$ in 2001 to $19.4 \%$ in 2006. A simple difference-in-difference analysis indicates that the rising entrepreneurship rate is associated with the increasing coverage. Since the program is targeted at the poor, who are less likely to be entrepreneurs, the relationship between program size and entrepreneurship is indeed negative across municipalities. However, Fig. 2 also shows that this relationship is flatter in 2006, which suggests that entrepreneurship has grown more in areas with higher program coverage.

Nonetheless, that relationship might have already been changing before the program started. In this case, the curve in 2002 would be flatter than the one in 2001. Figure 2 reveals that these curves are rather parallel, indicating that entrepreneurial rates in poor and rich municipalities had followed similar trends up to 2003.

An important way in which the program may affect entrepreneurship is through private transfers. This form of income is calculated as the sum of donations and other incomes, excluding retirement benefits, other pensions, rental earnings, and social benefits. If poor households adopt informal risk-sharing strategies, the percentage of them receiving private transfers should increase along with the liquidity provided by the program. In Table 1, we observe that this rate rose from $4.3 \%$ in 2001 to $7.7 \%$ in 2006.

\section{Empirical strategy}

The empirical strategy consists of a difference-in-difference model estimated using a three-period dataset. In this model, the first difference is across municipalities, which vary in terms of future coverage. The systematic distinctions among them are controlled by fixed effects. The second difference is between before (2001), during (2004), and after (2006) the expansion of the program. As discussed above, the program coverage has been strongly driven by the municipal quotas, so it grew independently from idiosyncratic changes in the entrepreneurship rate across municipalities. According to Proposition 1, presented below, this condition is sufficient for the identification of the overall effect of the program using a model with municipality-level fixed effects. Moreover, the identification assumption is weak enough to ignore the fact that some households are more likely to go after the benefit than others. The reason is that self-selection at the local level is not a concern when the comparison of treated and control observations occurs between municipalities, and not within municipalities.
Fig. 2 Relationship between entrepreneurship and program coverage. Entrepreneurship rate is measured by the proportion of small entrepreneurs per municipality. '2006 - 01 difference' is the difference between entrepreneurship rates in 2006 and 2001 per municipality. Program coverage is measured by the proportion of households participating in the program in 2006. Municipalities where the program coverage was greater than 5 p.p. in 2001 are not included

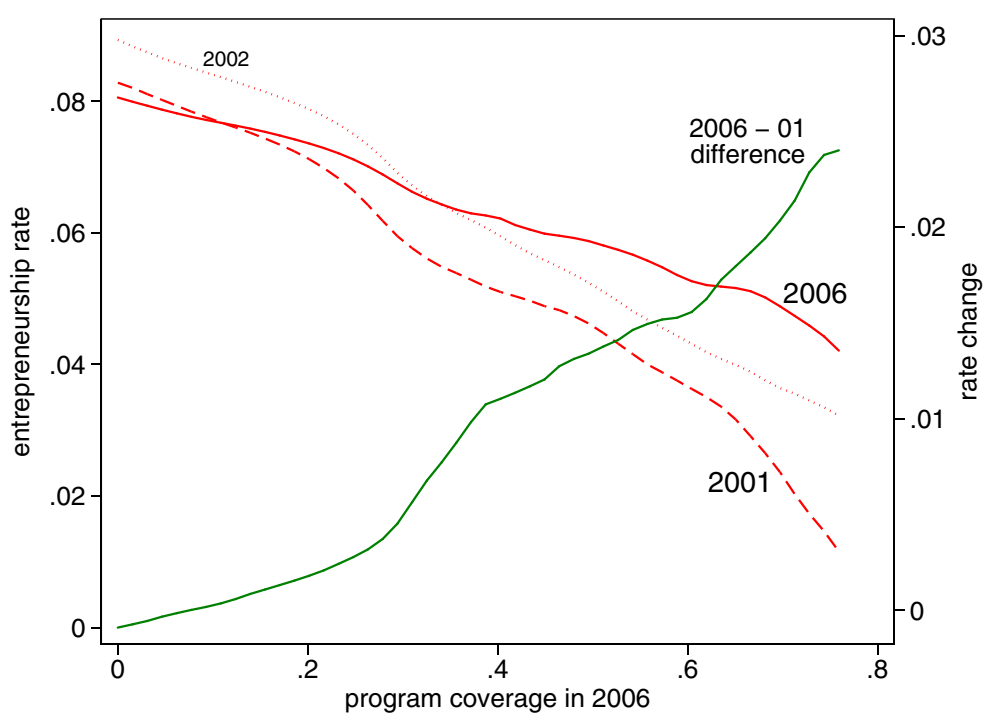


Furthermore, we introduce a formal test to verify whether the indirect effect is different for individuals who receive and do not receive the benefit (Proposition 2). This test replaces the individual-level randomization adopted by Duflo and Saez (2003) and Crépon et al. (2013) to separate the direct effect from the indirect effect. Once the homogeneity in the indirect effect is confirmed, the overall effect can be decomposed, adjusting for the self-selection bias. ${ }^{9}$

\subsection{Fixed-effect model}

Let $y_{i v t}$ be the decision of individual $i$ living in municipality $v$ at time $t$ to be an entrepreneur. This decision is determined by a linear model:

$y_{i v t}=\beta_{0}+\beta_{1} d_{i v t}+\beta_{2} \bar{d}_{v t}+\mu_{v}+\mu_{t}+u_{i v t}$,

where $\mu_{v}$ is the municipality fixed effect, $\mu_{t}$ is the period-specific effect, $u_{i v t}$ is the zero-mean random term, $d_{i v t}$ is the individual treatment indicator, and $\bar{d}_{v t}$ is the proportion of individuals receiving treatment in the same municipality (program coverage).

Following Eq. (2), coefficient $\beta_{1}$ is defined as the direct effect on participants, coefficient $\beta_{2}$ is the indirect effect on participants, and the sum of these coefficients, $\tau=\left(\beta_{1}+\beta_{2}\right)$, is the overall effect on participants. Individually, if someone receives the benefit, then the probability of their being an entrepreneur increases $\beta_{1}$ p.p. due to the direct effect and $\beta_{2}$ p.p. due to the indirect effect. Locally, if the program coverage increases 1 p.p., then the entrepreneurship rate will increase $\left(\beta_{1} \cdot 0.01\right)$ p.p. due to the direct effect on participants and $\left(\beta_{2} \cdot 0.01\right)$ p.p. due to the indirect effect on every eligible individual.

Most studies that compare treated households in covered villages and untreated households in uncovered villages (e.g., evaluations of PROGRESA/Opportunidades in Mexico) actually estimate the overall effect of the intervention, $\tau$. On the other hand, studies that compare individuals in the same cities or villages (e.g., Gasparini et al. 2009, Karlan and Zinman 2010, Blattman et al. 2014) are only estimating the direct effect, $\beta_{1}$. It is important to stress that recipients are as subject to indirect effects as other individuals in this model.

As explained above, the coverage of Bolsa Família at the municipality level has strongly depended on the

\footnotetext{
${ }^{9}$ All proofs are presented in the Appendix.
}

previously estimated poverty headcount. Therefore, it is reasonable to assume that the program coverage, $\bar{d}_{v t}$, is independent of the error term, $u_{i v t}$, once controlling for municipality fixed effects. Accordingly, the consistency of difference-in-difference estimates depends on the following identification assumption.

Assumption 1 (Partial Aggregate Independence, PAI) In Eq. 2,

$E\left[u_{i v t} \bar{d}_{v t} \mid d_{i v t}\right]=0$.

Given the choice made by individual $i$ of participating in the program, $d_{i v t}$, the proportion of individuals who are allowed to make this choice is orthogonal to the individual decision of being an entrepreneur. This assumption does not imply that $d_{i v t}$ is exogenous. If the distribution of benefits within municipalities is systematically correlated to unobservables, $E\left[\operatorname{Cov}\left(u_{i v t}, d_{i v t} \mid v, t\right)\right] \neq 0$, then $E\left[u_{i v t} d_{i v t}\right] \neq 0$. Although the program size is defined by the municipal quotas, the assignment of benefits at the local level can still be self-selective. In this case, the estimator for both coefficients, $\beta_{1}$ and $\beta_{2}$, will be asymptotically biased according to the following lemma.

Lemma 1 (Selection Bias) If the PAI assumption holds, then the least squares estimators for $\beta_{1}$ and $\beta_{2}$ have the following asymptotic property:

$\widehat{\beta_{1}} \stackrel{p}{\rightarrow} \beta_{1}+\frac{E\left[u_{i v t} d_{i v t}\right]}{\operatorname{Var}\left(d_{i v t}\right)-\operatorname{Var}\left(\bar{d}_{v t}\right)}$,
$\widehat{\beta_{2}} \stackrel{p}{\rightarrow} \beta_{2}-\frac{E\left[u_{i v t} d_{i v t}\right]}{\operatorname{Var}\left(d_{i v t}\right)-\operatorname{Var}\left(\bar{d}_{v t}\right)}$.

Note that the asymptotic biases cancel each other, so the estimator for $\tau=\left(\beta_{1}+\beta_{2}\right)$ will be consistent if $\bar{d}_{v t}$ is exogenous. Therefore, self-selection may be an issue if one compares individuals in the same city or village, but it is not if one compares cities and villages as a whole. Finally, the following proposition states the consistency of the identification strategy.

Proposition 1 (Consistent estimator for the overall effect) Consider the following equation:

$y_{i v t}=\beta_{0}+\tau \bar{d}_{v t}+\mu_{v}+\mu_{t}+u_{i v t}$ 
If Eq. (2) is the true model, then the least squares (LS) estimator for $\tau$ in Eq. (3) is the sum of the $L S$ estimators for $\beta_{1}$ and $\beta_{2}$ in Eq. (2):

$\widehat{\tau}=\widehat{\beta}_{1}+\widehat{\beta}_{2}$.

Moreover, if the PAI Assumption holds, then the LS estimator for $\tau$ in Eq. (3) is consistent:

$\widehat{\tau} \stackrel{p}{\rightarrow} \beta_{1}+\beta_{2}$.

Proposition 1 implies that the overall effect of the program, $\tau$, can be consistently estimated if we just omit $d_{i v t}$ in Eq. (2). Accordingly, we estimate Eq. (3) using a three-period data, with the standard errors clustered by municipality. For the sake of robustness, we also include individual and local control variables in the main model and estimate another model with census-tract fixed effects. If the self-selection bias is proportional to the program size, $\bar{d}_{v t}$, violating the PAI assumption, then estimates conditional on census-tract fixed effects should be different (less biased) than those conditional on municipality fixed effects.

\subsection{Instrumental variable approach}

One may argue that the PAI assumption is not reasonable because part of the variance of municipality coverage might be explained by unobservables related to the labor market. To consider only changes predicted by the municipal quotas, rather than changes caused by idiosyncratic behavior, we also estimate an IV model. In this model, the local coverage need not be strictly driven by observables, but it can be just partially affected by the program's initial design.

Assumption 2 (Instrumental variable assumption) Given the ex ante poverty level, $p_{v t}$, and unobserved fixed variables, the municipal quota, $q_{v t}$, is orthogonal to $u_{i v t}$.

The municipal quota is proxied by the interaction between the target coverage in 2006 (calculated in 2001), $q_{v 2}$, and year dummies, whereas the ex-ante poverty level is proxied by the interaction between the poverty headcount in 2002, $p_{v 0}$, and year dummies. Then the equation for the program coverage, $\bar{d}_{v t}$, is:

$$
\begin{aligned}
\bar{d}_{v t}= & \gamma_{0}+\gamma_{1} q_{v 2} \cdot I(t=2004)+\gamma_{2} q_{v 2} \cdot I(t=2006) \\
& +\gamma_{3} p_{v 0} \cdot I(t=2004)+\gamma_{4} p_{v 0} \cdot I(t=2006) \\
& +\theta_{v}+\theta_{t}+e_{i v t} .
\end{aligned}
$$

The IV assumption implies that the residual relationship between occupational choice and municipal quota does not change over time, unless by means of the growth of the program. Note that the constant relationship between occupational choices and the initial poverty headcount is controlled by the fixed effect, $\theta_{v}$, and changes in this relationship is controlled by the interaction between $p_{v 0}$ and year dummies. The remaining variance in municipal quotas should be driven by the fact that they were outdated in 2004 and 2006 and subject to error.

Since the instrument is defined at the municipality level, the predicted change in the intervention also happens at the municipality level. Therefore, if the program coverage, $\bar{d}_{v t}$, is replaced by the individual treatment, $d_{i v t}$, in Eqs. (3) and (4), the IV estimator will remain the same. ${ }^{10}$ This result reinforces the concept of overall effect defined above. Once the instrument is defined at the cluster level (e.g., randomization of treated villages), the comparison between treated and untreated individuals also happens at the cluster level-i.e., across villages rather than between individuals. On the one hand, this IV approach can be used to separate the actual treatment effect from the intention-to-treat effect (Crépon et al. 2015). On the other hand, the estimand cannot be interpreted as the result of a direct effect only.

\subsection{Separating direct and indirect effects}

Unfortunately, estimating Eq. (3) does not reveal whether the effect of program size comes from either a direct response of individuals receiving the transfer or an indirect effect that also affects individuals outside the program. Nonetheless, the PAI assumption is also sufficient for the indirect effect, $\beta_{2}$, to be consistently estimated using only the sample of non-participant individuals (with $d_{i v t}=0$ ):

$$
\begin{aligned}
y_{i v t \mid(d=0)}= & \beta_{0,(d=0)}+\tau_{(d=0)} \bar{d}_{v t} \\
& +\mu_{v,(d=0)}+\mu_{t,(d=0)}+u_{i v t \mid(d=0)}
\end{aligned}
$$

\footnotetext{
$\overline{{ }^{10} \text { See Section }} \mathrm{A}$ in the online Appendix.
} 
Non-participants are subject to an overall effect, $\tau_{(d=0)}$, that only comprises the indirect impact of the program, $\beta_{2,(d=0)}=\tau_{(d=0)}$. The next step is to infer whether the indirect effect is similar for participants and non-participants-i.e., $\beta_{2,(d=0)}=\beta_{2,(d=1)}=$ $\beta_{2}$. If it is different, the marginal indirect effect, as well as the marginal overall effect, should change as new individuals are added to the program. Thus the dose-response function of program coverage should be nonlinear. This idea is formally stated in the next proposition.

Proposition 2 (Test for heterogeneity of the indirect effect) If the indirect effect of the intervention is different for participants and non-participants, then the overall effect must be nonlinear.

As long as the overall effect is linear, we can also infer that $\beta_{2,(d=0)}=\beta_{2,(d=1)}=\beta_{2}$. Using Lemma 1, a consistent estimator for the direct effect can be calculated by subtracting the estimated bias from $\hat{\beta}_{1}$ in Eq. (2):

$\tilde{\beta}_{1}=\hat{\beta}_{1}-\left(\hat{\tau}_{(d=0)}-\hat{\beta}_{2}\right)$.

Accordingly, inference on the direct effect is made using seemingly unrelated regressions (SUR) of Eqs. (2) and (5).

\section{Main results}

\subsection{First-stage regressions}

Before moving to the main results, we first analyze the relationship between program coverage and municipal quotas, shown in Table 2. Even controlling for poverty in 2002 and changes in the relationship between poverty and program coverage over time, the municipal quotas are found to have a strong correlation with coverage. As the program grows, the relationship with quotas becomes stronger, but the relationship with initial poverty becomes weaker. Moreover, other social indicators, such as enrollment rate, child mortality, coverage of sewer system and proportion of home owners, do not have a significant relationship with the treatment.

The way that treatment is defined is also critical. After controlling for local fixed effects, all individual covariates are balanced with respect to program coverage. On the other hand, covariates remain heavily unbalanced with respect to the individual benefit. This finding illustrates the essence of the PAI assumption. Within municipalities, the distribution of benefits is far from random, which makes the individual assignment to treatment endogenous even if we control for local fixed effects. In this setting, however, the individual assignment does not affect the distribution of benefits across municipalities.

\subsection{Overall effect}

This section presents and discusses the overall effect of Bolsa Família on the probability of being an entrepreneur. Table 3 shows the estimates obtained using eight different models. Model (1), which does not include fixed effects and does not control for poverty, suggests that the relationship between entrepreneurship and program coverage is small and negative. Although this model includes covariates such as race, age and education, results tend to be biased because the program targets the poorest municipalities. After controlling for initial poverty, in model (2), the estimated relationship becomes positive and significant. This result holds for all models that include local fixed effects.

Models (3), (4) and (5) include fixed effects in different levels - i.e., municipality and census tract. As predicted by Proposition 1, which states that the within-municipality program assignment does not affect estimates for the overall effect, the coefficient does not change if we use fixed effects at a lower level. According to these models, a 10 p.p. increase in local coverage raises the entrepreneurship rate by 0.4 p.p. Considering the baseline rate of $7 \%$ and the current coverage of $19 \%$, the program might be responsible for an increase of $10 \%$ in the entrepreneurship rate, keeping everything else constant. ${ }^{11}$

In models (6) and (7), the PAI assumption is relaxed and the local coverage is instrumented by the municipal quota. The estimated effect is higher in these models, but not significantly different. Model (7) also includes the ex-ante poverty and social indicators that

\footnotetext{
${ }^{11}$ This effect happens mostly by increasing services, such as tailoring, shoe repair, automotive repair and taxi driving. The remaining effect comes from sales business, while the effect on manufacturing is very close to zero. See Table B3 in the online Appendix.
} 
Table 2 First-stage regression, relationship between quota and program coverage

\begin{tabular}{|c|c|c|c|c|c|c|}
\hline & \multicolumn{5}{|c|}{ Program coverage, $\bar{d}$} & \multirow{2}{*}{$\begin{array}{l}\text { Ind. benef., } d \\
\text { (6) }\end{array}$} \\
\hline & (1) & (2) & (3) & (4) & $(5)$ & \\
\hline Quota & $\begin{array}{l}0.044 \\
(0.036)\end{array}$ & & & & & \\
\hline Quota $\times$ year $=2004(a)$ & $\begin{array}{l}0.508 * * * \\
(0.036)\end{array}$ & $\begin{array}{l}0.400 * * * \\
(0.023)\end{array}$ & $\begin{array}{l}0.400 * * * \\
(0.023)\end{array}$ & $\begin{array}{l}0.513 * * * \\
(0.035)\end{array}$ & $\begin{array}{l}0.516 * * * \\
(0.035)\end{array}$ & $\begin{array}{l}0.095 * * \\
(0.045)\end{array}$ \\
\hline Quota $\times$ year $=2006(b)$ & $\begin{array}{l}0.713 * * * \\
(0.043)\end{array}$ & $\begin{array}{l}0.616 * * * \\
(0.030)\end{array}$ & $\begin{array}{l}0.616 * * * \\
(0.030)\end{array}$ & $\begin{array}{l}0.732 * * * \\
(0.044)\end{array}$ & $\begin{array}{l}0.734 * * * \\
(0.044)\end{array}$ & $\begin{array}{l}0.114 * * \\
(0.051)\end{array}$ \\
\hline Poverty in 2002 & $\begin{array}{l}0.179 * * * \\
(0.033)\end{array}$ & & & & & \\
\hline Poverty in $2002 \times$ year $=2004$ & $\begin{array}{l}-0.119 * * * \\
(0.034)\end{array}$ & & & $\begin{array}{l}-0.120 * * * \\
(0.033)\end{array}$ & $\begin{array}{l}-0.123 * * * \\
(0.034)\end{array}$ & $\begin{array}{l}0.268 * * * \\
(0.042)\end{array}$ \\
\hline Poverty in $2002 \times$ year $=2006$ & $\begin{array}{l}-0.145^{* * * *} \\
(0.035)\end{array}$ & & & $\begin{array}{l}-0.128 * * * \\
(0.034)\end{array}$ & $\begin{array}{l}-0.130 * * * \\
(0.034)\end{array}$ & $\begin{array}{l}0.374 * * * \\
(0.042)\end{array}$ \\
\hline Age $(\times 10)$ & $\begin{array}{l}0.004 \\
(0.004)\end{array}$ & $\begin{array}{l}0.003 \\
(0.002)\end{array}$ & $\begin{array}{l}0.003 \\
(0.003)\end{array}$ & $\begin{array}{l}0.003 \\
(0.002)\end{array}$ & $\begin{array}{l}0.003 \\
(0.002)\end{array}$ & $\begin{array}{l}0.135 * * * \\
(0.021)\end{array}$ \\
\hline Aquared age $(\times 100)$ & $\begin{array}{l}-0.001 \\
(0.001)\end{array}$ & $\begin{array}{l}0.000 \\
(0.000)\end{array}$ & $\begin{array}{l}0.000 \\
(0.000)\end{array}$ & $\begin{array}{l}0.000 \\
(0.000)\end{array}$ & $\begin{array}{l}0.000 \\
(0.000)\end{array}$ & $\begin{array}{l}-0.018 * * * \\
(0.003)\end{array}$ \\
\hline White & $\begin{array}{l}0.008 * * * \\
(0.001)\end{array}$ & $\begin{array}{l}0.000 \\
(0.000)\end{array}$ & $\begin{array}{l}0.000 \\
(0.000)\end{array}$ & $\begin{array}{l}0.000 \\
(0.000)\end{array}$ & $\begin{array}{l}0.000 \\
(0.000)\end{array}$ & $\begin{array}{l}-0.023 * * * \\
(0.002)\end{array}$ \\
\hline Black & $\begin{array}{l}-0.003 * \\
(0.002)\end{array}$ & $\begin{array}{l}0.000 \\
(0.001)\end{array}$ & $\begin{array}{l}0.000 \\
(0.001)\end{array}$ & $\begin{array}{l}0.000 \\
(0.001)\end{array}$ & $\begin{array}{l}0.000 \\
(0.001)\end{array}$ & $\begin{array}{l}0.007 * \\
(0.004)\end{array}$ \\
\hline Married & $\begin{array}{l}0.000 \\
(0.001)\end{array}$ & $\begin{array}{l}0.000 \\
(0.000)\end{array}$ & $\begin{array}{l}0.000 \\
(0.000)\end{array}$ & $\begin{array}{l}0.000 \\
(0.000)\end{array}$ & $\begin{array}{l}0.000 \\
(0.000)\end{array}$ & $\begin{array}{l}0.058 * * * \\
(0.005)\end{array}$ \\
\hline Elementary education & $\begin{array}{l}-0.003 * * * \\
(0.001)\end{array}$ & $\begin{array}{l}0.000 \\
(0.000)\end{array}$ & $\begin{array}{l}0.000 \\
(0.000)\end{array}$ & $\begin{array}{l}0.000 \\
(0.000)\end{array}$ & $\begin{array}{l}0.000 \\
(0.000)\end{array}$ & $\begin{array}{l}-0.036^{* * *} \\
(0.004)\end{array}$ \\
\hline Primary education & $\begin{array}{l}-0.001 * \\
(0.001)\end{array}$ & $\begin{array}{l}0.000 \\
(0.000)\end{array}$ & $\begin{array}{l}0.000 \\
(0.000)\end{array}$ & $\begin{array}{l}0.000 \\
(0.000)\end{array}$ & $\begin{array}{l}0.000 \\
(0.000)\end{array}$ & $\begin{array}{l}-0.037 * * * \\
(0.003)\end{array}$ \\
\hline High school & $\begin{array}{l}0.000 \\
(0.001)\end{array}$ & $\begin{array}{l}0.000 \\
(0.000)\end{array}$ & $\begin{array}{l}0.000 \\
(0.000)\end{array}$ & $\begin{array}{l}0.000 \\
(0.000)\end{array}$ & $\begin{array}{l}0.000 \\
(0.000)\end{array}$ & $\begin{array}{l}-0.023 * * * \\
(0.003)\end{array}$ \\
\hline $\log$ of population & $\begin{array}{l}-0.009 * * * \\
(0.002)\end{array}$ & $\begin{array}{l}0.029 * \\
(0.017)\end{array}$ & $\begin{array}{l}0.029 * \\
(0.017)\end{array}$ & $\begin{array}{l}0.029 * \\
(0.017)\end{array}$ & $\begin{array}{l}0.029 * \\
(0.017)\end{array}$ & $\begin{array}{l}0.066^{* * * *} \\
(0.024)\end{array}$ \\
\hline Elementary enrollment rate & & & & $\begin{array}{l}0.035 \\
(0.027)\end{array}$ & $\begin{array}{l}0.035 \\
(0.027)\end{array}$ & $\begin{array}{l}0.057 \\
(0.038)\end{array}$ \\
\hline Primary enrollment rate & & & & $\begin{array}{l}-0.017 \\
(0.015)\end{array}$ & $\begin{array}{l}-0.018 \\
(0.015)\end{array}$ & $\begin{array}{l}-0.005 \\
(0.022)\end{array}$ \\
\hline High school enrollment rate & & & & $\begin{array}{l}0.010 \\
(0.011)\end{array}$ & $\begin{array}{l}0.010 \\
(0.011)\end{array}$ & $\begin{array}{l}-0.007 \\
(0.016)\end{array}$ \\
\hline Child mortality $(\times 1000)$ & & & & $\begin{array}{l}-0.029 \\
(0.059)\end{array}$ & $\begin{array}{l}-0.029 \\
(0.059)\end{array}$ & $\begin{array}{l}-0.091 \\
(0.089)\end{array}$ \\
\hline Coverage of sewer system & & & & $\begin{array}{l}-0.006 \\
(0.014)\end{array}$ & $\begin{array}{l}-0.006 \\
(0.014)\end{array}$ & $\begin{array}{l}0.011 \\
(0.021)\end{array}$ \\
\hline Prop. of home owners & & & & $\begin{array}{l}-0.022 \\
(0.024)\end{array}$ & $\begin{array}{l}-0.021 \\
(0.024)\end{array}$ & $\begin{array}{l}-0.019 \\
(0.036)\end{array}$ \\
\hline
\end{tabular}


Table 2 (continued)

Program coverage, $\bar{d}$

Municipality fixed-effects

Census tract fixed-effects

Year dummies

Number of observations

test $(a)=(b)=0, F$-stat
(1)

(2)

No

No

Yes

129,080

$142.0 * * *$

Yes

No

Yes

129,080

$249.7 * * *$
(3)

No Yes

Yes No

Yes Yes

129,080

$250.6^{* * * *}$

Ind. benef., $d$

***, **, *Statistical significant at the $1 \%, 5 \%$, and $10 \%$ levels, respectively. Sample includes only men with high school diploma or less. Standard errors in parentheses are clustered by municipality

Table 3 Overall effect of cash transfers on entrepreneurship

\begin{tabular}{|c|c|c|c|c|c|c|c|c|}
\hline & \multicolumn{8}{|c|}{ Decision of being a small entrepreneur } \\
\hline & \multicolumn{2}{|l|}{ OLS } & \multicolumn{3}{|l|}{ FE } & \multicolumn{3}{|l|}{ IV } \\
\hline & (1) & (2) & (3) & (4) & (5) & (6) & (7) & (8) \\
\hline program coverage, $\bar{d}$ & $\begin{array}{l}-0.012 \\
(0.009)\end{array}$ & $\begin{array}{l}0.037 * * * \\
(0.014)\end{array}$ & $\begin{array}{l}0.047 * * * \\
(0.016)\end{array}$ & $\begin{array}{l}0.038 * * \\
(0.018)\end{array}$ & $\begin{array}{l}0.039 * * \\
(0.018)\end{array}$ & $\begin{array}{l}0.063 * * * \\
(0.023)\end{array}$ & $\begin{array}{l}0.067 * \\
(0.034)\end{array}$ & \\
\hline individual benefit, $d$ & & & & & & & & $\begin{array}{l}0.063 * * * \\
(0.024)\end{array}$ \\
\hline Poverty in 2002 & & $\begin{array}{l}-0.059 * * * \\
(0.010)\end{array}$ & & & & & & \\
\hline Poverty in $2002 \times$ year $=2004$ & & $\begin{array}{l}0.012 \\
(0.012)\end{array}$ & & $\begin{array}{l}0.014 \\
(0.012)\end{array}$ & $\begin{array}{l}0.011 \\
(0.012)\end{array}$ & & $\begin{array}{l}0.008 \\
(0.014)\end{array}$ & \\
\hline Poverty in $2002 \times$ year $=2006$ & & $\begin{array}{l}0.011 \\
(0.012)\end{array}$ & & $\begin{array}{l}0.011 \\
(0.013)\end{array}$ & $\begin{array}{l}0.008 \\
(0.013)\end{array}$ & & $\begin{array}{l}0.004 \\
(0.018)\end{array}$ & \\
\hline Municipality fixed-effects & No & No & Yes & Yes & No & Yes & Yes & Yes \\
\hline Census tract fixed-effects & No & No & No & No & Yes & No & No & No \\
\hline Year dummies & Yes & Yes & Yes & Yes & Yes & Yes & Yes & Yes \\
\hline Individual covariates & Yes & Yes & Yes & Yes & Yes & Yes & Yes & Yes \\
\hline Social indicators & No & No & No & No & No & No & Yes & No \\
\hline Number of observations & 129,080 & 129,080 & 129,080 & 129,080 & 129,080 & 129,080 & 129,080 & 129,046 \\
\hline Underidentification LM test & & & & & & $80.1 * * *$ & $94.8 * * *$ & $110.3^{* * *}$ \\
\hline Weak identification $F$-test & & & & & & $249.7 * * *$ & $150.2 * * *$ & $195.0 * * *$ \\
\hline Overidentification $J$-test & & & & & & 1.157 & 0.738 & 0.105 \\
\hline
\end{tabular}

$* * *, * *, *$ Statistical significant at the $1 \%, 5 \%$, and $10 \%$ levels, respectively. Standard errors in parentheses are clustered by municipality. Sample includes only men with high school diploma or less. Columns (1) and (2) present the regression coefficients obtained by ordinary least squares (OLS). Columns (3), (4), and (5) present the fixed-effect regressions (FE) obtained using the within-group method. Columns (6), (7), and (8) present the fixed-effect, Instrumental-variable regressions (IV) with "program coverage" and "individual benefit" instrumented by the interactions between municipal quota and year dummies 
Table 4 Nonlinear, indirect, and direct effects of cash transfers on entrepreneurship

\begin{tabular}{|c|c|c|c|c|c|c|}
\hline & \multicolumn{6}{|c|}{ Decision of being a small entrepreneur } \\
\hline & \multicolumn{2}{|l|}{$\mathrm{O}$} & \multicolumn{2}{|l|}{$\mathrm{FE}$} & \multicolumn{2}{|l|}{ IV } \\
\hline & (1) & (2) & (3) & (4) & (5) & (6) \\
\hline program coverage, $\bar{d}$ & $\begin{array}{l}0.067 * \\
(0.039)\end{array}$ & $\begin{array}{l}0.066 \\
(0.040)\end{array}$ & $\begin{array}{l}0.062 * * * \\
(0.018)\end{array}$ & $\begin{array}{l}0.048 * * \\
(0.021)\end{array}$ & $\begin{array}{l}0.078 * * * \\
(0.024)\end{array}$ & $\begin{array}{l}0.062 * \\
(0.037)\end{array}$ \\
\hline Squared coverage, $\bar{d}^{2}$ & $\begin{array}{l}-0.041 \\
(0.061)\end{array}$ & $\begin{array}{l}-0.066 \\
(0.073)\end{array}$ & & & & \\
\hline Individual benefit, $d$ & & & $\begin{array}{l}-0.037 * * * \\
(0.005)\end{array}$ & $\begin{array}{l}-0.036^{* * * *} \\
(0.007)\end{array}$ & $\begin{array}{l}-0.043^{* * *} \\
(0.006)\end{array}$ & $\begin{array}{l}-0.037 * * * \\
(0.010)\end{array}$ \\
\hline Poverty in $2002 \times$ year $=2004$ & & $\begin{array}{l}0.015 \\
(0.012)\end{array}$ & & $\begin{array}{l}0.013 \\
(0.013)\end{array}$ & & $\begin{array}{l}0.009 \\
(0.016)\end{array}$ \\
\hline Poverty in $2002 \times$ year $=2006$ & & $\begin{array}{l}0.017 \\
(0.015)\end{array}$ & & $\begin{array}{l}0.018 \\
(0.016)\end{array}$ & & $\begin{array}{l}0.011 \\
(0.021)\end{array}$ \\
\hline Municipality fixed-effects & Yes & Yes & Yes & Yes & Yes & Yes \\
\hline Year dummies & Yes & Yes & Yes & Yes & Yes & Yes \\
\hline Individual covariates & Yes & Yes & Yes & Yes & Yes & Yes \\
\hline No. of obs.-all sample & 129,080 & 129,080 & 129,046 & 129,046 & 129,046 & 129,046 \\
\hline No. of obs. $-d=0$ & & & 113,088 & 113,088 & 113,088 & 113,088 \\
\hline Overidentification $J$-test & & & & & 2.68 & 1.44 \\
\hline
\end{tabular}

$* * *, * *, *$ Statistical significant at the $1 \%, 5 \%$, and $10 \%$ levels, respectively. Standard errors in parentheses are clustered by municipality. Sample includes only men with high school diploma or less. Columns (1) and (2) present the fixed-effect model with quadratic effect of program coverage. Columns (3)-(6) present the estimates of the indirect effect (program coverage) and direct effect (individual benefit), with bias correction given by Lemma 1, estimated using seemingly unrelated regressions (SUR). FE columns show fixed-effect regressions obtained using the within-group method. IV columns show fixed-effect, instrumental-variable regressions with "program coverage" instrumented by the interactions between municipal quotas and year dummies

had changed over time, such as child mortality, sewer coverage, share of house owners, and school enrollment rates. Although the standard error increases, the estimated effect does not change. Thus, the overall change in entrepreneurship does not seem to be driven by initial poverty or other socioeconomic improvements.

In model (8), the dummy of individual benefit replaces the local coverage, but the instrumental variable is the same as before. As expected, the estimated coefficient barely changes because the cluster-level instrument compares observations between municipalities and not within municipalities. Namely, local coverage and individual benefit are interchangeable as a treatment variable, whose coefficients can both be interpreted as the overall effect of the program on participants.

The estimated overall effect between 4 and 6 p.p. is found to be larger than PROGRESA's in Mexico, estimated to be 0.9 p.p. by Bianchi and Bobba (2013), and some microcredit programs, which do not look to increase entrepreneurship at the extensive margin (Banerjee et al. 2015a; Angelucci et al 2015; Crépon et al 2015). ${ }^{12}$ However, it is half as large as the Targeted Ultra-Poor Program's in Bangladesh (Bandiera et al. 2017) and the Youth Opportunities Program's in Uganda (Blattman et al. 2014). These two programs, nevertheless, are particularly intended to promote entrepreneurship, with the transfer being conditional on productive investments.

\subsection{Direct and indirect effects}

To estimate the indirect effect of the program, we first have to verify whether it is constant or not. According to Proposition 2, if the overall effect is linear, then the indirect effect of the program is similar for participants and non-participants. The first columns of Table 4 show that the coefficient of squared coverage is, in fact, not significant. Since the hypothesis of linear overall effect is not rejected, we estimate the

\footnotetext{
${ }^{12}$ Exceptions are the programs studied by Attanasio et al. (2015) and Augsburg et al. (2015).
} 
Table 5 Indirect and direct effects on entrepreneurship by population density

\section{Entrepreneurial Decision}

FE

(1)

$0.039 *$
$(0.022)$
$-0.010 * *$
$(0.004)$
$-0.046 * * *$
$(0.005)$
-0.000
$(0.001)$

Regression coefficients program coverage, $\bar{d}$

$\bar{d} * \log$ pop. density

Individual benefit, $d$

$d \times \log$ pop. density

Effect on the bottom $20 \%$ of density program coverage, $\bar{d}$

Individual benefit, $d$

$0.062 * * *$
$(0.017)$
$-0.045 * * *$
$(0.005)$

Effect on the top $20 \%$ of density

program coverage, $\bar{d}$

$\begin{array}{ll}0.012 & 0.021 \\ (0.031) & (0.059) \\ -0.047 * * * & -0.053 * * * \\ (0.007) & (0.011) \\ \text { Yes } & \text { Yes } \\ \text { Yes } & \text { Yes } \\ \text { Yes } & \text { Yes } \\ 129,046 & 129,046 \\ 113,088 & 113,088\end{array}$

Individual benefit, $d$

Municipality fixed-effects

Year dummies

Individual covariates

No. of obs.-all sample

No. of obs. $-d=0$

Overidentification $J$-test
IV

(3)

(4)

$\begin{array}{ll}0.060 * * & 0.026 \\ (0.026) & (0.048) \\ -0.007 * & -0.014 \\ (0.004) & (0.017) \\ -0.053 * * * & -0.045^{* * *} \\ (0.007) & (0.013) \\ -0.000 & 0.001 \\ (0.002) & (0.005)\end{array}$

0.017
$(0.031)$
-0.013
$(0.012)$
$-0.048 * * *$
$(0.007)$
-0.002
$(0.003)$

$0.049 * * *$

(0.021)

$-0.044 * * *$

(0.008)

$(0.023)$

0.060

(0.038)

$-0.053 * * *$

$-0.048 * * *$

(0.011)

(0.006)

$-0.014$

(0.087)

-0.041 *

(0.024)

Yes

Yes

Yes

129,046

113,088

4.94

$* * *, * *$ * Statistical significant at the $1 \%, 5 \%$, and $10 \%$ levels, respectively. Standard errors in parentheses are clustered by municipality. Sample includes only men with high school diploma or less. The top panel presents the regression coefficients of interest. The bottom panel presents the predicted effects on the top $20 \%$ and the bottom $20 \%$ of the population density distribution. Columns (1) and (2) have the results from the fixed-effect model (FE) estimated using the within-group method. Columns (3) and (4) have the results from the fixed-effect, instrumental-variable regression (IV) with "program coverage" instrumented by the interactions between municipal quota and year dummies. Columns (2) and (4) include poverty in 2002 times year dummies as control. In each column, coefficients are estimated using seemingly unrelated regressions (SUR) with bias correction given by Lemma 1

indirect effect of the program using only the sample of non-participants. In all models, these estimates are greater than the overall effect discussed above. Then the direct response to the program should be negative, after adjusting for the bias according to Lemma 1 .

The results indicate that, on one hand, cash transfers reduce the probability of participants starting their own business by 3-4 p.p. On the other hand, the amount of cash transferred to poor villages seems to encourage the creation of new businesses. A 10 p.p. increase in the program size tends to raise the entrepreneurship rate of poor individuals by $0.5-0.8$ p.p. Because of this positive indirect effect, the net impact of cash transfers on entrepreneurship is also positive.

This difference suggests that small entrepreneurs are not as responsive to financial constraints as to other general equilibrium mechanisms. Nevertheless, there are several possible explanations for the negative direct response and the positive indirect effect on entrepreneurship. ${ }^{13}$ In Section 5, we will find that the

\footnotetext{
${ }^{13}$ The negative direct effect is not likely to be driven by conditionalities on education because participants with no children also reduce entrepreneurial activity. See Table B4 in the online Appendix.
} 
indirect response is related to the promotion of informal financing mechanisms among poor households.

\subsection{Indirect effect and population density}

In terms of policy implications, it is worth knowing where the indirect effect of cash transfers is higher. To identify large cities and small villages and have a sense of geographical differences, we construct a variable of population density using the Demographic Census. However, the matching between these data and the ones used so far is not possible for all municipalities, particularly the small ones. Accordingly, we match clusters of municipalities defined by their size, metropolitan status, and state.

The findings, presented in Table 5, reveal that the higher the population density, the lower the indirect effect. The direct effect, on the other hand, does not change with the population density. As a result, the net effect of cash transfers is significantly positive in low-density areas, as observed before, and insignificant in highly populated areas. This result implies that the program is not effective in promoting entrepreneurship in large cities, because the negative direct response from recipients offsets the small indirect effect. The program's impact is concentrated in small villages, which probably have less aggregate liquidity.

\section{Potential mechanisms}

\subsection{Transfers between households}

The first explanation for the positive indirect effect on entrepreneurship is the increasing number of households transferring money to each other. As in Angelucci and De Giorgi (2009) study, the indirect effect of cash transfers might be driven by the existence of risk-sharing strategies within villages. If poor households follow these strategies, the increasing liquidity can promote an informal financial market for those who do not have access to formal credit and insurance. Unfortunately, we have no information on lenders for those who start a business and on the specific amount of transfers received from other households.

Using another household survey, which reports more detailed information on income and expenditures, we calculated the probability of participating households to lend or transfer money to another household unit. Figure 3 shows that program participants are indeed more likely to make transfers to other households in each section of income distribution. On average, participants are about $40 \%$ more likely to be a moneylender than non-participants with the same level of income. This observed difference cannot be strictly interpreted as a causal effect, but it
Fig. 3 Probability of transferring or lending money to another household. Estimates made using the Brazilian Consumer Expenditure Survey (POF) 2008-2009. The bars represent the proportion of households that have transferred or lent money to another household in the last 90 days. The dashed line represents the proportion of households receiving a conditional cash transfer. Income deciles are calculated using household per capita income

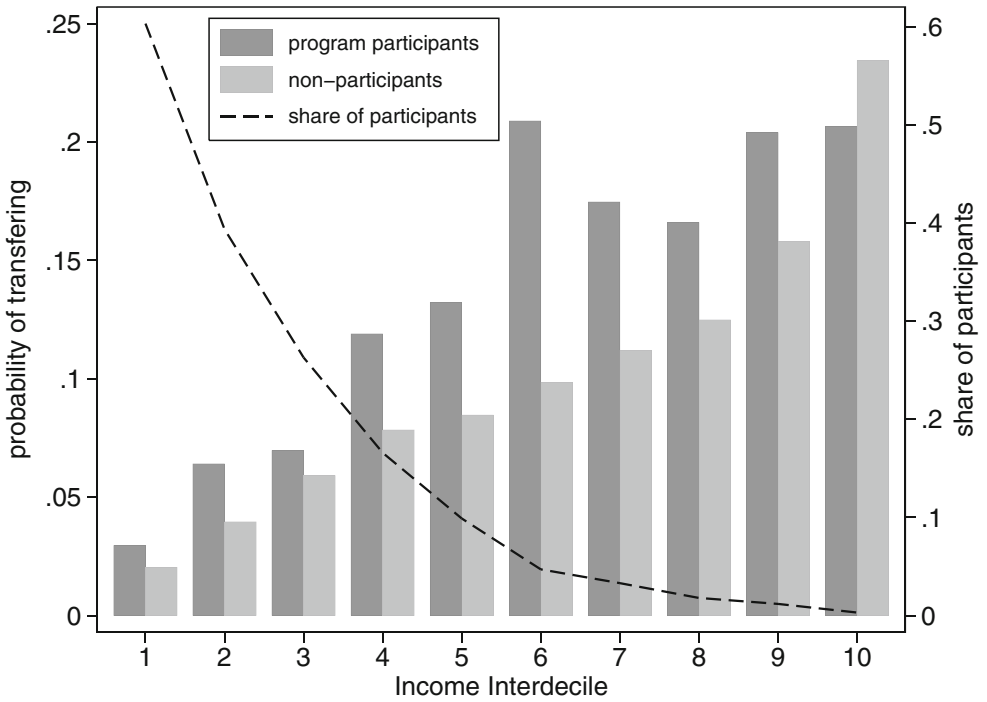


confirms the presumption that the cash transfer flows in the community through private transfers. Moreover, assuming that program participants declare that they are poorer than they look in household surveys, the observed difference represents a lower-bound estimate for the causal effect.

Back to the original dataset, PNAD interviewers are oriented to ask households about all their sources of income, including transfers received from other households. The total value of these transfers goes under the entries of "donations" and "other incomes" and can be separated from major sources, such as labor earnings, retirement benefits, other pensions, rental earnings, and social programs. Table 6 presents the estimated effect of program coverage on the probability of non-participants receiving "other transfers." According to the results in columns (1) and (2), a 10 p.p. increase in local coverage raises this probability by $1.1-1.6$ p.p. This result suggests that the higher the proportion of beneficiaries in the community, the higher the probability of being financially helped by another household. This result is consistent with the ones found by Attanasio et al. (2015) and Karlan and Zinman (2010), who show that access to credit increases mutual assistance between households.

While individuals with better job opportunities may use these transfers as a safety net, individuals with fewer job opportunities may use them to start

Table 6 Indirect effect of cash transfers on private transfers and entrepreneurship

\begin{tabular}{|c|c|c|c|c|c|}
\hline & \multicolumn{3}{|c|}{ Receiving private transfers } & \multicolumn{2}{|c|}{ Entrepreneurial decision } \\
\hline & $\begin{array}{l}\text { FE } \\
\text { (1) }\end{array}$ & $\begin{array}{l}\text { IV } \\
\text { (2) }\end{array}$ & $\begin{array}{l}\mathrm{FE} \\
\text { (3) }\end{array}$ & $\begin{array}{l}\text { FE } \\
\text { (4) }\end{array}$ & $\begin{array}{l}\text { IV } \\
(5)\end{array}$ \\
\hline program coverage, $\bar{d}$ & $\begin{array}{l}0.111 * * * \\
(0.021)\end{array}$ & $\begin{array}{l}0.160 * * * \\
(0.026)\end{array}$ & & $\begin{array}{l}0.046 * * \\
(0.019)\end{array}$ & $\begin{array}{l}0.042 \\
(0.026)\end{array}$ \\
\hline $\bar{d} \times$ effect on private transfers & & & & $\begin{array}{l}0.450 * * * \\
(0.162)\end{array}$ & $\begin{array}{l}0.617 * * \\
(0.270)\end{array}$ \\
\hline $\bar{d} \times$ jobless & & & $\begin{array}{l}0.297 * * * \\
(0.037)\end{array}$ & & \\
\hline $\bar{d} \times$ informal & & & $\begin{array}{l}0.116^{* * *} \\
(0.021)\end{array}$ & & \\
\hline $\bar{d} \times$ formal & & & $\begin{array}{l}0.031 \\
(0.023)\end{array}$ & & \\
\hline $\bar{d} \times$ entrepreneur & & & $\begin{array}{l}0.011 \\
(0.031)\end{array}$ & & \\
\hline Municipality fixed-effects & Yes & Yes & Yes & Yes & Yes \\
\hline Year dummies & Yes & Yes & Yes & Yes & Yes \\
\hline Individual covariates & Yes & Yes & Yes & Yes & Yes \\
\hline Number of observations & 112,976 & 112,976 & 112,976 & 113,054 & 113,054 \\
\hline Underidentification LM test & & $86.48 * * *$ & & & $68.97 * * *$ \\
\hline Weak identification $F$-test & & $301.6^{* * *}$ & & & $180.7 * * *$ \\
\hline Overidentification $J$-test & & 1.61 & & & 0.00 \\
\hline
\end{tabular}

$* * *, * *, *$ Statistical significant at the $1 \%, 5 \%$, and $10 \%$ levels, respectively. Standard errors in parentheses are clustered by municipality. Sample includes only men with high school diploma or less. In columns (1), (2), and (3), the outcome is the probability of receiving private transfers. In columns (4) and (5), the outcome is the probability of being an entrepreneur. "Effect on private transfers" is calculated by a regression of private transfers on program coverage interacting with 2001 municipality characteristics. The coefficient of interaction between "effect on private transfers" and "program coverage" represents how much the effect of program coverage on entrepreneurial decision changes if its predicted effect on private transfers increases. FE columns show fixed-effect regressions obtained using the within-group method. IV columns show fixed-effect, instrumental-variable regressions with "program coverage" instrumented by the interactions between municipal quotas and year dummies 
their own business. Since we do not know if current entrepreneurs received other transfers before, we cannot conclude that these transfers are actually invested. The only conclusion that can be drawn is that the effect on receiving other transfers is the highest among those who need them most. Namely, the effect is significantly higher for the jobless, followed by informal workers (see column (3) in Table 6).

To verify whether the indirect effects on entrepreneurship and private transfers are related, we include the interaction between program coverage and the predicted effect on private transfers in the regression (columns (4) and (5) in Table 6). This predicted effect is calculated by interacting coverage and several municipality characteristics in the estimation of private transfers. These "firststep" interactions already reveal, for instance, that the indirect effect of cash transfers on both private transfers and entrepreneurship is higher in less populated areas, with higher school enrollment rates and higher labor informality. Using the predicted effect on private transfers, we find that the larger this effect, the higher the indirect effect on entrepreneurship. Although this is just a rough estimation, it indicates that entrepreneurial activity has increased through the promotion of informal risk-sharing mechanisms.

\subsection{Aggregate demand and investment opportunities}

If the indirect effect on entrepreneurship came from a shock in the aggregate demand, we should observe other changes in the labor market. For instance, increasing investment opportunities should also affect the decision of well-educated men to become entrepreneurs. Moreover, with higher purchasing power, either more jobs should be created or higher salaries should be provided. Accordingly, we also estimate the indirect effect of cash transfers on these outcomes.

The first two columns of Table 7 confirm that the program size has no significant effect on the probability of well-educated men becoming entrepreneurs. Thus we cannot say the program has encouraged the creation of local businesses in general. The effect on

Table 7 Indirect effect of cash transfers on other entrepreneurs, employment and wages

\begin{tabular}{|c|c|c|c|c|c|c|}
\hline & \multicolumn{2}{|c|}{$\begin{array}{l}\text { High-educated } \\
\text { entrep. decision }\end{array}$} & \multicolumn{2}{|c|}{$\begin{array}{l}\text { Low-educated } \\
\text { employment }\end{array}$} & \multicolumn{2}{|c|}{$\begin{array}{l}\text { Low-educated } \\
\text { employees' wages }\end{array}$} \\
\hline & $\begin{array}{l}\mathrm{FE} \\
(1)\end{array}$ & $\begin{array}{l}\text { IV } \\
(2)\end{array}$ & $\begin{array}{l}\mathrm{FE} \\
(3)\end{array}$ & $\begin{array}{l}\text { IV } \\
(4)\end{array}$ & $\begin{array}{l}\mathrm{FE} \\
(5)\end{array}$ & $\begin{array}{l}\text { IV } \\
(6)\end{array}$ \\
\hline program coverage, $\bar{d}$ & $\begin{array}{l}0.028 \\
(0.126)\end{array}$ & $\begin{array}{l}0.098 \\
(0.158)\end{array}$ & $\begin{array}{l}-0.024 \\
(0.025)\end{array}$ & $\begin{array}{l}-0.048 \\
(0.030)\end{array}$ & $\begin{array}{l}-0.373 \\
(1.019)\end{array}$ & $\begin{array}{l}-0.553 \\
(1.391)\end{array}$ \\
\hline $\bar{d} \times$ private sector & & & & & $\begin{array}{l}0.698 \\
(1.006)\end{array}$ & $\begin{array}{l}0.960 \\
(1.378)\end{array}$ \\
\hline Municipality fixed-effects & Yes & Yes & Yes & Yes & Yes & Yes \\
\hline Year dummies & Yes & Yes & Yes & Yes & Yes & Yes \\
\hline Individual covariates & Yes & Yes & Yes & Yes & Yes & Yes \\
\hline Number of observations & 9,340 & 9,340 & 113,054 & 113,054 & 58,066 & 58,066 \\
\hline Underidentification LM test & & $38.12 * * *$ & & $86.42 * * *$ & & $88.68 * * *$ \\
\hline Weak identification $F$-test & & $88.26 * * *$ & & $302.1 * * *$ & & $73.85 * * *$ \\
\hline Overidentification $J$-test & & 1.95 & & 0.04 & & 1.94 \\
\hline
\end{tabular}

$* * *, * *, *$ Statistical significant at the $1 \%, 5 \%$, and $10 \%$ levels, respectively. Standard errors in parentheses are clustered by municipality. In columns (1) and (2), the outcome is the probability of being an entrepreneur and the sample only includes individuals with college degree or equivalent. In columns (3) and (4), the outcome is the probability of less-educated individuals, excluding public servants, being employed in either the formal sector or the informal sector. In columns (5) and (6), the outcome is the log of earnings per hour in the main occupation, and the sample only includes less-educated workers formally employed in either the private or public sector. FE columns show fixed-effect regressions obtained using the within-group method. IV columns show fixed-effect, instrumental-variable regressions with "program coverage" instrumented by the interactions between municipal quota and year dummies 
entrepreneurship is concentrated among less-educated workers, who are probably connected to a network of eligible households. Furthermore, the estimates in columns (3) and (4) do not corroborate the hypothesis of job creation. Even though more less-educated men have taken the decision to be an entrepreneur, the program has had no effect on their overall employment rate. This result suggests that the program does not affect the demand side of the labor market. It may have just affected the occupational choice on the supply side.

Although Bolsa Família has not significantly affected the employment rate, the effect on the demand side could have been just on wages. It is worth noting that the estimated effect on wages can be misleading if the program has some influence on local prices. Accordingly, we use wages of less-educated public employees as a proxy for labor costs. Then, the real effect on aggregate demand is assessed by the difference between documented employees in the private sector and public servants. Indeed, the estimated coefficient for the interaction between program coverage and the private sector, in the last two columns of Table 7 , is not significant.

\subsection{Other occupational choices and the eligibility effect}

To understand where the marginal entrepreneurs come from, we also investigate the effect of the program on other occupational choices. Besides entrepreneur, the alternatives are jobless, formal employee, informal employee, and informal self-employed. Table 8 presents the direct and indirect effects of the program

Table 8 Indirect and direct effects of cash transfers on other occupational choices

\begin{tabular}{|c|c|c|c|c|c|}
\hline & Entrep. & Jobless & $\begin{array}{l}\text { Formal } \\
\text { employee }\end{array}$ & $\begin{array}{l}\text { Informal } \\
\text { employee }\end{array}$ & $\begin{array}{l}\text { Informal } \\
\text { self-emp. }\end{array}$ \\
\hline \multicolumn{6}{|l|}{ Fixed-effect model } \\
\hline \multirow[t]{2}{*}{ program coverage, $\bar{d}$} & $0.062 * * *$ & 0.023 & 0.032 & $-0.081 * * *$ & -0.037 \\
\hline & $(0.018)$ & $(0.025)$ & $(0.029)$ & $(0.027)$ & $(0.028)$ \\
\hline \multirow[t]{2}{*}{ Individual benefit, $d$} & $-0.037 * * *$ & $0.030 * * *$ & $-0.040 * * *$ & $0.024 * *$ & $0.023 * *$ \\
\hline & $(0.005)$ & $(0.009)$ & $(0.012)$ & $(0.010)$ & $(0.011)$ \\
\hline Municipality fixed-effects & Yes & Yes & Yes & Yes & Yes \\
\hline Year dummies & Yes & Yes & Yes & Yes & Yes \\
\hline Individual covariates & Yes & Yes & Yes & Yes & Yes \\
\hline No. of obs.-all sample & 129,046 & 129,046 & 129,046 & 129,046 & 129,046 \\
\hline No. of obs. $-d=0$ & 113,088 & 113,088 & 113,088 & 113,088 & 113,088 \\
\hline \multicolumn{6}{|l|}{ Instrumental-variable model } \\
\hline \multirow[t]{2}{*}{ program coverage, $\bar{d}$} & $0.078 * * *$ & 0.047 & -0.002 & $-0.097 * * *$ & -0.026 \\
\hline & $(0.024)$ & $(0.03)$ & $(0.038)$ & $(0.033)$ & $(0.037)$ \\
\hline \multirow[t]{2}{*}{ Individual benefit, $d$} & $-0.043 * * *$ & $0.032 * * *$ & $-0.037 * *$ & 0.008 & $0.040 * * *$ \\
\hline & $(0.006)$ & $(0.012)$ & $(0.015)$ & $(0.014)$ & $(0.015)$ \\
\hline Municipality fixed-effects & Yes & Yes & Yes & Yes & Yes \\
\hline Year dummies & Yes & Yes & Yes & Yes & Yes \\
\hline Individual covariates & Yes & Yes & Yes & Yes & Yes \\
\hline No. of obs.-all sample & 129,046 & 129,046 & 129,046 & 129,046 & 129,046 \\
\hline No. of obs. $-d=0$ & 113,088 & 113,088 & 113,088 & 113,088 & 113,088 \\
\hline
\end{tabular}

$* * *, * *, *$ Statistical significant at the $1 \%, 5 \%$, and $10 \%$ levels, respectively. Standard errors in parentheses are clustered by municipality. Sample includes only men with high school diploma or less. All coefficients are estimated using seemingly unrelated regressions (SUR). The indirect effect (program coverage) is estimated using the sample of non-participants, whereas the direct effect (individual benefit) is estimated using all sample and bias corrected according to Lemma 1. Fixed-effect models are estimated using the withingroup method. In the instrumental-variable models, "program coverage" is instrumented by the interactions between municipal quotas and year dummies 
on the probability of being in each one of these categories, vis-á-vis being in any other category.

The estimated indirect coefficients indicate that the program has no significant effect on the proportion of jobless men in the areas covered. The program does not have a significant indirect effect on the proportion of formal employees either. Once again, the hypothesis that the money injected into local economies shifts the demand for workers is not supported by these results. The strongest indirect effect is on the proportion of informal employees. Assuming that the labor market is segregated, the program may have given the financial opportunity to informal workers to open their own business. As already explained, the cash transferred by Bolsa Família has probably flowed into the hands of these workers by means of private transfers among poor households.

As regards the direct impact on program participants, the negative effect on entrepreneurship looks symmetric to the positive effect on the jobless rate. This negative effect could be related to the income effect that unearned income has on labor supply. However, the reduction in labor supply only happens among formal workers (entrepreneurs and documented employees). ${ }^{14}$ Thus program participants reduce labor supply not because leisure is a normal good, as the classical model predicts. A more plausible reason is that they do not want to lose the benefit for uncertain earnings. Unlike formal workers, informal workers do not have their income tracked by the government, so they do not need to stop working to stay officially eligible for the transfer. ${ }^{15}$

According to the official records of MDS, almost $40 \%$ of cases of benefit cancellation are due to income improvement. Also, the main reported reason for this type of cancellation is the identification of formal workers' earnings in the Ministry of Labor and Employment's dataset, the so-called RAIS.

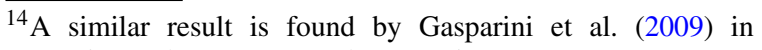
Argentina and Amarante et al. (2011) in Uruguay.

${ }^{15}$ The direct effects on labor supply in the formal and informal sectors might be distinct due to differences in workers' ability. However, the same pattern emerges in subsamples of individuals with and without a high school diploma. See Table B5 in the online Appendix.
}

\subsection{Confounding factors}

The identification of all effects estimated so far essentially depends on the assumption that the relationship between poverty and entrepreneurship does not change over time, unless by means of the growth of the program. In other words, there is no convergence in the entrepreneurship rate across municipalities in Brazil. This convergence could be driven by other social programs or by the process of credit expansion. In the main results shown above (in Tables 3 and 4), we already include the interaction between initial poverty rate and year dummies. Once again, the estimated effect of Bolsa Família barely changed. Most of the endogeneity in the distribution of benefits across municipalities - but not between individuals-is controlled for using fixed effects, in addition to the instrumental variable (municipal quotas). Thus, poverty itself does not explain the growth in entrepreneurship unless by means of the growth of the program.

Another placebo test, presented in Table 9, is of changes before the program expanded in 2003. Columns (1) and (2) show that the growth of the program from 2001 to 2006 does not explain changes in entrepreneurship between 2001 and 2002. As regards the increasing access to credit, the decline in interest rates and the growth of personal loans started in 2005. Thus there is a small overlap between the investigated period (2001-2006) and the period of credit expansion in Brazil. ${ }^{16}$ Despite this small overlap, columns (3), (4) and (5) confirm that the estimated effect between 2001 and 2004 is still significantly positive.

Although the credit expansion started in the late 2000s, other microcredit programs have been in place since the 1990s. To test whether the results are driven by microcredit programs, we exclude from the sample the region where the largest and most significant program was introduced. The CrediAmigo program, created in 1997, is considered the largest microfinance program in the country, but it covers only municipalities in the Northeast region. Furthermore, the Northeast was the focus of other social programs intended to boost local economies. Columns (6), (7), and (8) of

\footnotetext{
${ }^{16}$ See Fig. 5 in the Appendix.
} 
Table 9 Overall effect of cash transfers on entrepreneurship, robustness analyses

\begin{tabular}{|c|c|c|c|c|c|c|c|c|}
\hline & \multicolumn{8}{|c|}{ Decision of being a small entrepreneur } \\
\hline & \multicolumn{2}{|c|}{$2001-2002$} & \multicolumn{3}{|c|}{ 2001-2004 } & \multicolumn{3}{|c|}{ excluding Northeast } \\
\hline & $\begin{array}{l}\mathrm{FE} \\
(1)\end{array}$ & $\begin{array}{l}\text { IV } \\
(2)\end{array}$ & $\begin{array}{l}\mathrm{FE} \\
(3)\end{array}$ & $\begin{array}{l}\text { IV } \\
(4)\end{array}$ & $\begin{array}{l}\text { IV } \\
(5)\end{array}$ & $\begin{array}{l}\mathrm{FE} \\
(6)\end{array}$ & $\begin{array}{l}\text { IV } \\
\text { (7) }\end{array}$ & $\begin{array}{l}\text { IV } \\
(8)\end{array}$ \\
\hline program coverage, $\bar{d}$ & & & $\begin{array}{l}0.062 * * * \\
(0.022)\end{array}$ & $\begin{array}{l}0.087 * * \\
(0.038)\end{array}$ & $\begin{array}{l}0.093 * \\
(0.050)\end{array}$ & $\begin{array}{l}0.076 * * * \\
(0.028)\end{array}$ & $\begin{array}{l}0.100 * * * \\
(0.035)\end{array}$ & $\begin{array}{l}0.097 * * \\
(0.044)\end{array}$ \\
\hline $\bar{d}$ in $2001-2006$ & $\begin{array}{l}0.023 \\
(0.016)\end{array}$ & $\begin{array}{l}0.033 \\
(0.021)\end{array}$ & & & & & & \\
\hline Poverty in 2002 times year $=2004$ & & & & & $\begin{array}{l}-0.003 \\
(0.016)\end{array}$ & & & $\begin{array}{l}0.015 \\
(0.021)\end{array}$ \\
\hline Poverty in $2002 \times$ year $=2006$ & & & & & & & & $\begin{array}{l}0.001 \\
(0.025)\end{array}$ \\
\hline Municipality fixed-effects & Yes & Yes & Yes & Yes & Yes & Yes & Yes & Yes \\
\hline Year dummies & Yes & Yes & Yes & Yes & Yes & Yes & Yes & Yes \\
\hline Individual covariates & Yes & Yes & Yes & Yes & Yes & Yes & Yes & Yes \\
\hline Number of observations & 83,570 & 83,570 & 84,391 & 84,391 & 84,391 & 91,514 & 91,514 & 91,514 \\
\hline Underidentification LM test & & $74.08 * * *$ & & $78.77 * * *$ & $87.41 * * *$ & & $76.28 * * *$ & $90.57 * * *$ \\
\hline Weak identification $F$-test & & $483.6^{* * *}$ & & $308.7 * * *$ & $211.9^{* * *}$ & & $261.4 * * *$ & $149.4 * * *$ \\
\hline Overidentification $J$-test & & 0.00 & & 0.00 & 0.00 & & 2.24 & 1.54 \\
\hline
\end{tabular}

$* * *, * *$ * Statistical significant at the $1 \%, 5 \%$, and $10 \%$ levels, respectively. Standard errors in parentheses are clustered by municipality. Sample includes only men with high school diploma or less. Columns (1) and (2) present the relationship between changes in entrepreneurship in 2001-2002 and program growth in 2001-2006. Columns (3)-(5) present the estimates of the overall effect between 2001 and 2004 (excluding 2006). Columns (6)-(8) present the estimates of the overall effect in regions other than the Northeast. FE columns show fixed-effect regressions obtained using the within-group method. IV columns show fixed-effect, instrumental-variable regressions with "program coverage" instrumented by the interactions between municipal quota and year dummies

Table 9 show that the estimated effect on entrepreneurship increases after omitting that region. Thus the results do not seem to be a consequence of the growth in microcredit or other development programs.

\section{Conclusion}

Designing evaluations to assess direct and indirect effects of public policies is critical to understanding their implications. In the case of a cash transfer program, the identification of spillovers reveals that its impact goes well beyond cash and conditionalities, uncovering the role of inter-household exchanges within the informal economy. Thus, the overall effect, which is often estimated by comparing villages in this type of intervention, is not always driven by the direct response of recipients to the program.
Although the rate of small entrepreneurs has grown $10 \%$ due to the CCT programs in Brazil, it does not mean that their recipients could start a business if they were not financially constrained. The cash transfer has actually reduced their willingness to start a formal business in comparison to their neighbors. This negative response is related to increasing informality, which seems to be the best option for program participants to keep receiving both labor earnings and social benefits.

On the other hand, the amount of cash transferred to poor areas has indirectly lifted the creation of new businesses, particularly among those who would be otherwise in the informal sector. Therefore, it was not the increase in household income, or the relief from the financial constraint, that has encouraged these entrepreneurs. A plausible explanation for the indirect effect is the existence of informal risk-sharing 
arragements among the poor. Once the program increases the liquidity is in these arrangements, recipients will be more willing to assist other households with their investments.

Since financial constraints do not necessarily hinder the process of business creation, ${ }^{17}$ providing grants or access to credit could just crowd out informal financial sources. This may explain why micro-entrepreneurship programs are sometimes not so effective at the extensive margin. To increase their effectiveness, these programs could be built upon the informal system in place by, for instance, including the participation of local micro-investors and group monitoring.

Finally, it is worth stressing that this study has limitations. Although we do not need randomization of the individual benefit to identify direct and indirect effects, the growth of the program across municipalities was not fully random. Its growth may have followed other local initiatives, which we cannot control for. Only a setting in which villages are randomly covered by the program would yield consistent results. Also, the suggested mechanism of indirect effects is just speculative. More detailed information on households' social network and transfers between households would help us to give better answers.

Acknowledgments This paper benefited from comments from Richard Akresh, David Albouy, Mary Arends-Kuenning, Dan Bernhardt, Murillo Campello, George Deltas, Habiba Djebbari, Francisco Ferreira, Giorgia Giovannetti, Roger Koenker, Ron Laschever, Darren Lubotsky, Gabriel Natividad, Marcelo Neri, seminar participants at the University of Amsterdam, University of Illinois at Urbana-Champaign, University of Illinois at Chicago, PUC-Rio, PIMES-UFPE, Cedeplar-UFMG, and IPEA, conference participants at the 68th European Meeting of the Econometric Society, GDN 14th Global Development Conference, 2014 AAEA Meeting, 2014 North America Summer Meeting of the Econometric Society, and 9th IZA/World Bank Conference on Employment and Development, and two anonymous referees. I also appreciate the useful discussions with Diloá Athias, Simon Bordenave, João B. Duarte, Paulo H. Vaz, Marco Rocha, Fábio Soares, and Sergei Soares. The views, findings and conclusions expressed in this paper, however, are those of his author alone.

Open Access This article is distributed under the terms of the Creative Commons Attribution 4.0 International License (http:// creativecommons.org/licenses/by/4.0/), which permits unrestricted use, distribution, and reproduction in any medium, provided you give appropriate credit to the original author(s) and the source, provide a link to the Creative Commons license, and indicate if changes were made.

\section{Appendix. Proofs of Section 3}

\section{A.1 Proof of Lemma 1}

To simplify the proof, we start with the following within-group version of Eq. (2):

$y_{i v t}^{*}=\beta_{1} d_{i v t}^{*}+\beta_{2} \bar{d}_{v t}^{*}+u_{i v t}$

where $y_{i v t}^{*}=\left(y_{i v t}-\bar{y}_{v}-\bar{y}_{t}\right), \quad d_{i v t}^{*}=$ $\left(d_{i v t}-\bar{d}_{v}-\bar{d}_{t}\right)$, and $\bar{d}_{v t}^{*}=\left(\bar{d}_{v t}-\overline{\bar{d}}_{v}-\overline{\bar{d}}_{t}\right)$.

Let $S_{x} \equiv \sum_{t} \sum_{v} \sum_{i} x_{i v t}$. By construction, $S_{d^{*}}=$ $S_{\bar{d}^{*}}=0$ and $S_{d^{*} \bar{d}^{*}}=S_{\bar{d}^{* 2}}$. Then, the least squares (LS) estimator can be written as follows:

$$
\begin{aligned}
& {\left[\begin{array}{c}
\widehat{\beta_{1}} \\
\widehat{\beta_{2}}
\end{array}\right]=\frac{1}{\left[S_{d^{* 2}} S_{\bar{d}^{* 2}}-\left(S_{d^{*} \bar{d}^{*}}\right)^{2}\right]}\left[\begin{array}{cc}
S_{\bar{d}^{* 2}} & -S_{d^{*} \bar{d}^{*}} \\
-S_{d^{*} \bar{d}^{*}} & S_{d^{* 2}}
\end{array}\right]\left[\begin{array}{c}
S_{d^{*} y^{*}} \\
S_{\bar{d}^{*} y^{*}}
\end{array}\right]} \\
& =\frac{1}{\left(S_{d^{* 2}}-S_{\vec{d}^{* 2}}\right)}\left[\begin{array}{l}
S_{d^{*} y^{*}}-S_{\bar{d}^{*} y^{*}} \\
\frac{S_{d^{* 2}}}{S_{\vec{d}^{* 2}}} S_{\bar{d}^{*} y^{*}}-S_{d^{*} y^{*}}
\end{array}\right] \\
& =\left[\begin{array}{l}
\beta_{1}+\frac{1}{\left(S_{\left.d^{* 2}-S_{\bar{d}^{* 2}}\right)}\right.}\left(S_{d^{*} u}-S_{\bar{d}^{*} u}\right) \\
\beta_{2}+\frac{1}{\left(S_{d^{* 2}}-S_{\bar{d}^{* 2}}\right)}\left(\frac{S_{d^{* 2}}}{S_{\vec{d}^{* 2}}} S_{\bar{d}^{*} u}-S_{d^{*} u}\right)
\end{array}\right] .
\end{aligned}
$$

Consider that there exists a sample size $N$ so that for every sample with $n \geq N, \bar{d}_{v t} \in(0,1)$ for some $i v t$-observation. This condition implies that $S_{d^{* 2}}>$ $S_{\bar{d}^{* 2}}$ for a large enough sample. Finally, by the Law of Large Numbers:

$$
\begin{aligned}
\widehat{\beta_{1}} & \stackrel{p}{\rightarrow} \beta_{1}+\frac{1}{\left[\operatorname{Var}\left(d_{i v t}\right)-\operatorname{Var}\left(\bar{d}_{v t}\right)\right]}\left[E\left(u_{i v t} d_{i v t}^{*}\right)-E\left(u_{i v t} \bar{d}_{v t}^{*}\right)\right] \\
& =\beta_{1}+\frac{E\left(u_{i v t} d_{i v t}^{*}\right)}{\left[\operatorname{Var}\left(d_{i v t}\right)-\operatorname{Var}\left(\bar{d}_{v t}\right)\right]}
\end{aligned}
$$

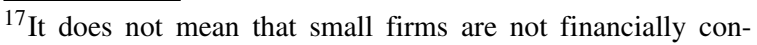
strained.
} 
and

$$
\begin{aligned}
\widehat{\beta}_{2} & \stackrel{p}{\rightarrow} \beta_{2}+\frac{1}{\left[\operatorname{Var}\left(d_{i v t}\right)-\operatorname{Var}\left(\bar{d}_{v t}\right)\right]}\left[\frac{\operatorname{Var}\left(d_{i v t}\right)}{\operatorname{Var}\left(\bar{d}_{v t}\right)} E\left(u_{i v t} \bar{d}_{v t}^{*}\right)-E\left(u_{i v t} d_{i v t}^{*}\right)\right] \\
& =\beta_{2}-\frac{E\left(u_{i v t} d_{i v t}^{*}\right)}{\left[\operatorname{Var}\left(d_{i v t}\right)-\operatorname{Var}\left(\bar{d}_{v t}\right)\right]},
\end{aligned}
$$

where $E\left(u_{i v t} \bar{d}_{v t}^{*}\right)=0$ because of the PAI assumption.

\section{A. 2 Proof of Proposition 1}

Let $y_{i v t}^{*}, d_{i v t}^{*}$, and $\bar{d}_{v t}^{*}$ be village-period mean-centred versions of $y_{i v t}, d_{i v t}$, and $\bar{d}_{v t}$, respectively.

For the first part, the LS estimator for $\tau$ in Eq. (3) is the following:

$$
\begin{aligned}
\widehat{\tau} & =\frac{\sum_{i v t} \bar{d}_{v t}^{*} y_{i v t}^{*}}{\sum_{i v t} \bar{d}_{v t}^{* 2}} \\
& =\frac{\widehat{\beta}_{1} \sum_{i v t} \bar{d}_{v t}^{*} d_{i v t}^{*}+\widehat{\beta}_{2} \sum_{i v t} \bar{d}_{v t}^{*} \bar{d}_{v t}^{*}+\sum_{i v t} \bar{d}_{v t}^{*} \widehat{u}_{i v t}}{\sum_{i v t} \bar{d}_{v t}^{* 2}} \\
& =\frac{\widehat{\beta}_{1} \sum_{v t} \bar{d}_{v t}^{*} \sum_{i} d_{i v t}^{*}}{\sum_{v t} \sum_{i} \bar{d}_{v t}^{* 2}}+\widehat{\beta}_{2} \\
& =\widehat{\beta}_{1}+\widehat{\beta}_{2} .
\end{aligned}
$$

For the second part, Lemma 1 is applied so that

$\widehat{\tau} \stackrel{p}{\rightarrow} \beta_{1}+\beta_{2}$.

\section{A.3 Proof of Proposition 2}

Suppose the true equation to be estimated is:

$y_{i v t}=\beta_{0}+\beta_{1} d_{i v t}+\beta_{2} \bar{d}_{v t}+\beta_{3} d_{i v t} \bar{d}_{v t}+\mu_{v}+\mu_{t}+u_{i v t}$,

so that coefficient $\beta_{3}$ captures the difference in the indirect effect between participants and nonparticipants.

If we aggregate the observations at the villageperiod level, then:

$\bar{y}_{v t}=\beta_{0}+\left(\beta_{1}+\beta_{2}\right) \bar{d}_{v t}+\beta_{3} \bar{d}_{v t}^{2}+\mu_{v}+\mu_{t}+\bar{u}_{v t}$ and the overall effect of $\bar{d}_{v t}$ becomes non-linear.
Fig. 4 Quantiles of $\log$ earnings per hour worked. "Small entrepreneurs" are those who are self-employed in a high-skilled job, contribute to social security, and/or have more than two employees. "Formal employees" are employed with documentation and/or contribute to social security. The "informal self-employed" perform a low-skilled activity and do not contribute to social security. Earnings comprise the net gain of the self-employed and salary and bonuses of employees

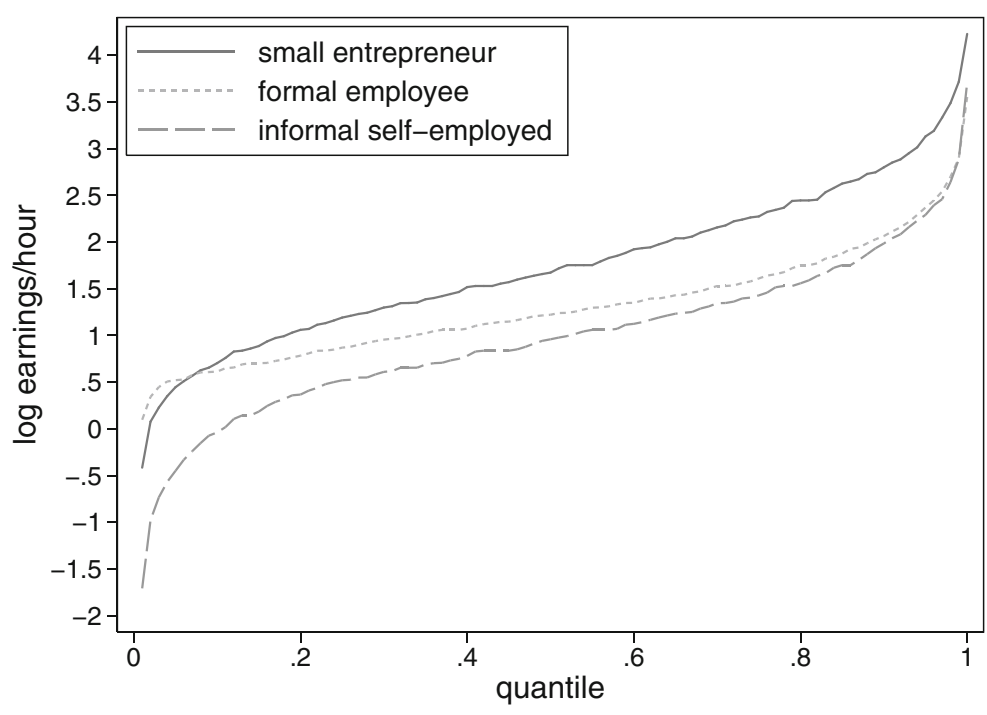


Fig. 5 Household debt outstanding and interest rate in Brazil. Source: Central Bank of Brazil. Debt series is deflated by the National Consumer Price Index (INPC)

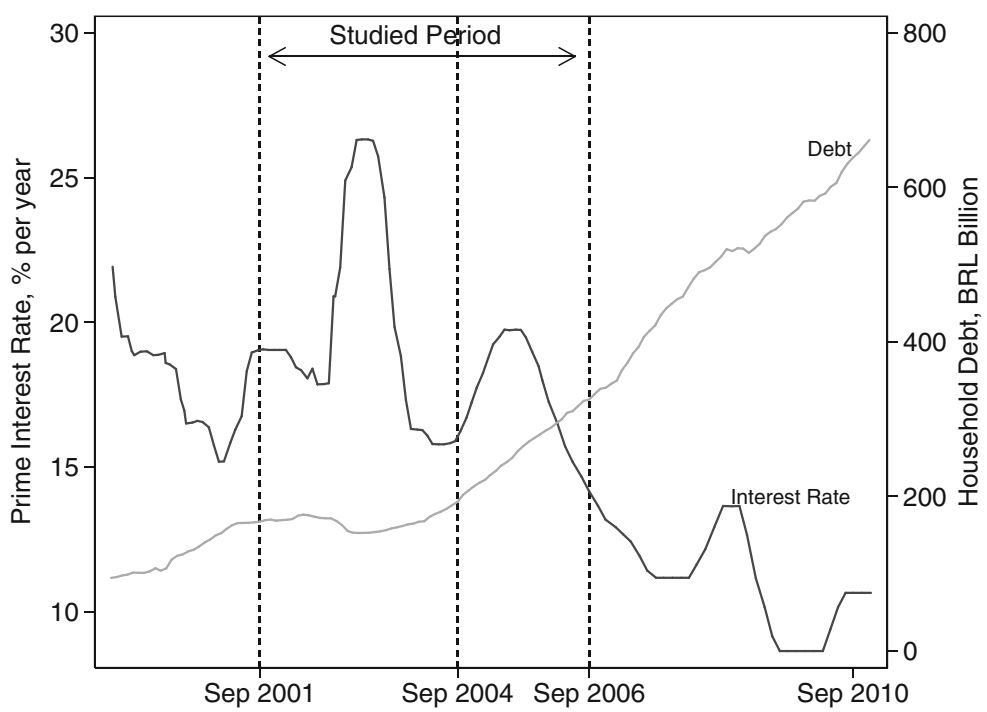

Table 10 Description of variables

Definition

Outcomes

Entrepreneur

Formal employee

Informal employee

Informal self-employed

Jobless

receiving private transfer

Individual variables

Age

White

Black

Married

Elementary education

Primary education

High school

Number of kids

Number of elderly

Migrant-last 5 years
Equal to one if self-employed in professional or technical occupation, self-employed in any other occupation and also contributing to social security, employer with more than two employees, or small employer contributing to social security, and zero otherwise

Equal to one if employed with documentation or contributing to social security, and zero otherwise

Equal to one if employed without documentation and not contributing to social security, and zero otherwise

Equal to one if self-employed in low-skilled occupation and not contributing to social security, and zero otherwise

Equal to one if not having a remunerated occupation, including unemployed and inactive adults, and zero otherwise

Equal to one if household received any non-labor income from private sources in the last 30 days, and zero otherwise.

Age of individual in years

Equal to one if self-declaration of skin color is white and zero otherwise

Equal to one if self-declaration of skin color is black and zero otherwise

Equal to one if married and zero otherwise

Equal to one if completed elementary education and zero otherwise

Equal to one if completed primary education and zero otherwise

Equal to one if completed high school education and zero otherwise

Number of people who are 14 years or less cohabiting the same residence

Number of people who are 60 years or more cohabiting the same residence

Equal to one if migrated to the municipality in the last 5 years and zero otherwise 
Table 10 (continued)

Definition

Municipality variables

Program coverage

Target coverage

Poverty headcount

Population

Population density

Elementary enrollment rate

Primary enrollment rate

High school enrollment rate

Child mortality

Coverage of sewer system

Prop. of house owners
Proportion of households receiving conditional cash transfers in the municipality

Proportion of households in the municipality that should receive a conditional cash transfer according to the official quota

Proportion of households whose per capita income is less than two minimum wages in the municipality

Number of inhabitants in the municipality

Number of inhabitants in the group of municipality over total area of the group

Proportion of kids between 7 and 10 years old enrolled at elementary school in the municipality

Proportion of kids between 11 and 14 years old enrolled at primary school in the municipality

Proportion of kids between 15 and 17 years old enrolled at high school in the municipality

Deaths per 1000 children under 5 years old in the municipality

Proportion of residences connected to sewer system in the municipality

Proportion of households living in their owned houses in the municipality

Table 11 Overall effect of cash transfers on entrepreneurship, estimated by bootstrap

\begin{tabular}{|c|c|c|c|c|c|c|c|c|}
\hline & \multicolumn{8}{|c|}{ Decision of being a small entrepreneur } \\
\hline & \multicolumn{2}{|l|}{ OLS } & \multicolumn{3}{|l|}{$\mathrm{FE}$} & \multicolumn{3}{|l|}{ IV } \\
\hline & (1) & (2) & (3) & (4) & $(5)$ & (6) & (7) & (8) \\
\hline program coverage, $\bar{d}$ & $\begin{array}{l}-0.012 \\
(0.009)\end{array}$ & $\begin{array}{l}0.037 * * * \\
(0.013)\end{array}$ & $\begin{array}{l}0.047 * * * \\
(0.016)\end{array}$ & $\begin{array}{l}0.038 * * \\
(0.020)\end{array}$ & $\begin{array}{l}0.039 * * \\
(0.019)\end{array}$ & $\begin{array}{l}0.063 * * * \\
(0.024)\end{array}$ & $\begin{array}{l}0.067 * \\
(0.031)\end{array}$ & \\
\hline individual benefit, $d$ & & & & & & & & $\begin{array}{l}0.063 * * * \\
(0.024)\end{array}$ \\
\hline Poverty in 2002 & & $\begin{array}{l}-0.059 * * * \\
(0.010)\end{array}$ & & & & & & \\
\hline Poverty in $2002 \times$ year $=2004$ & & $\begin{array}{l}0.012 \\
(0.013)\end{array}$ & & $\begin{array}{l}0.014 \\
(0.011)\end{array}$ & $\begin{array}{l}0.011 \\
(0.012)\end{array}$ & & $\begin{array}{l}0.008 \\
(0.013)\end{array}$ & \\
\hline Poverty in $2002 \times$ year $=2006$ & & $\begin{array}{l}0.011 \\
(0.012)\end{array}$ & & $\begin{array}{l}0.011 \\
(0.013)\end{array}$ & $\begin{array}{l}0.008 \\
(0.013)\end{array}$ & & $\begin{array}{l}0.004 \\
(0.017)\end{array}$ & \\
\hline Municipality fixed-effects & No & No & Yes & Yes & No & Yes & Yes & Yes \\
\hline Census tract fixed-effects & No & No & No & No & Yes & No & No & No \\
\hline Year dummies & Yes & Yes & Yes & Yes & Yes & Yes & Yes & Yes \\
\hline Individual covariates & Yes & Yes & Yes & Yes & Yes & Yes & Yes & Yes \\
\hline Social indicators & No & No & No & No & No & No & Yes & No \\
\hline Number of observations & 129,080 & 129,080 & 129,080 & 129,080 & 129,080 & 129,080 & 129,080 & 129,046 \\
\hline Underidentification LM test & & & & & & $80.1 * * *$ & $94.8 * * *$ & $110.3 * * *$ \\
\hline Weak identification $F$-test & & & & & & $249.7 * * *$ & $150.2 * * *$ & $195.0 * * *$ \\
\hline Overidentification $J$-test & & & & & & 1.157 & 0.738 & 0.105 \\
\hline
\end{tabular}

$* * *, * *, *$ Statistical significant at the $1 \%, 5 \%$, and $10 \%$ levels, respectively. Standard errors in parentheses are calculated by bootstrap with 200 replications. Sample includes only men with high school diploma or less. Columns (1) and (2) present the regression coefficients obtained by ordinary least squares (OLS). Columns (3), (4), and (5) present the fixed-effect regressions (FE) obtained using the within-group method. Columns (6), (7), and (8) present the fixed-effect, instrumental-variable regressions (IV) with "program coverage" and "individual benefit" instrumented by the interactions between municipal quota and year dummies 


\section{References}

Aghion, P., \& Bolton, P. (1997). A trickle-down theory of growth and development. Review of Economic Studies, 64(2), 151-172. https://doi.org/10.2307/2971707. http:// oup.prod.sis.lan/restud/article-pdf/64/2/151/4491029/64-2151.pdf.

Amarante, V., Manacorda, M., Vigorito, A., Zerpa, M. (2011). Social assistance and labor market outcomes: evidence from the uruguayan PANES. inter-American Development Bank. https://doi.org/10.2139/ssrn.1858039.

Angelucci, M., \& De Giorgi, G. (2009). Indirect effects of an aid program: how do cash transfers affect ineligibles' consumption? American Economic Review, 99(1), 486-508. https://doi.org/10.1257/aer.99.1.486. http://www. aeaweb.org/articles?id=10.1257/aer.99.1.486.

Angelucci, M., Giorgi, G.D., Rangel, M., Rasul, I. (2009). Village economies and the structure of extended family networks. BE Journal of Economic Analysis and Policy, 9(1), $1-46$.

Angelucci, M., Giorgi, G.D., Rangel, M., Rasulv I (2010). Family networks and school enrollment: evidence from a randomized social experiment. Journal of Public Economics, 94(3-4), 197-221. https://doi.org/10.1016/j.jpubec o.2009.12.002. http://www.sciencedirect.com/science/articl e/pii/S0047272709001637.

Angelucci, M., Karlan, D., Zinman, J. (2015). Microcredit impacts: evidence from a randomized microcredit program placement experiment by Compartamos Banco. American Economic Journal: Applied Economics, 7(1), 151-82. https://doi.org/10.1257/app.20130537. http://www.aeaweb. org/articles?id=10.1257/app.20130537.

Ardagna, S., \& Lusardi, A. (2010). Explaining international differences in entrepreneurship: the role of individual characteristics and regulatory constraints. In Lerner, J., \& Schoar, A. (Eds.) International differences in entrepreneurship (pp. 17-62). Chicago: Univeristy of Chicago Press, https://doi.org/10.7208/chicago/9780226473109.003.0002.

Attanasio, O., Augsburg, B., De Haas, R., Fitzsimons, E., Harmgart, H. (2015). The impacts of microfinance: evidence from joint-liability lending in Mongolia. American Economic Journal: Applied Economics, 7(1), 90-122. https://doi.org/10.1257/app.20130489. http://www.aeaweb. org/articles?id=10.1257/app.20130489.

Augsburg, B., De Haas, R., Harmgart, H., Meghir, C. (2015). The impacts of microcredit: evidence from Bosnia and Herzegovina. American Economic Journal: Applied Economics, 7(1), 183-203. https://doi.org/10.1257/app.2013 0272. http://www.aeaweb.org/articles?id=10.1257/app.201 30272.

Bandiera, O., Burgess, R., Gulesci, S., Rasul, I. (2009). Community networks and poverty reduction programmes: Evidence from Bangladesh STICERD - economic organisation and public policy discussion paper 15 . Suntory and Toyota international centres for economics and related disciplines, LSE.

Bandiera, O., Burgess, R., Das, N., Gulesci, S., Rasul, I., Sulaiman, M. (2017). Labor markets and poverty in village economies. Quarterly Journal of Economics, 132(2), 811-870. https://doi.org/10.1093/qje/qjx003.
Banerjee, A., Duflo, E., Glennerster, R., Kinnan, C. (2015a). The miracle of microfinance? evidence from a randomized evaluation. American Economic Journal: Applied Economics, 7(1), 22-53. https://doi.org/10.1257/app.2013 0533. http://www.aeaweb.org/articles?id=10.1257/app.201 30533.

Banerjee, A., Karlan, D., Zinman, J. (2015b). Six randomized evaluations of microcredit: introduction and further steps. American Economic Journal: Applied Economics, 7(1), 1-21. https://doi.org/10.1257/app.20140287. http:// www.aeaweb.org/articles?id=10.1257/app.20140287.

Banerjee, A.V., \& Duflo, E. (2005). Growth theory through the lens of development economics. In Aghion, P., \& Durlauf, S. (Eds.) Handbook of economic growth, (Vol. 1 pp. 473552): Elsevier. chap 7.

Banerjee, A.V., \& Newman, A.F. (1993). Occupational choice and the process of development. Journal of Political Economy, 101(2), 274-298. https://doi.org/10.1086/261876.

Barros, R., Carvalho, M., Franco, S., Mendonça, R. (2008). A importância das cotas para a focalização do programa bolsa família. Discussion papers 1349, Instituto de Pesquisa Econômica Aplicada (IPEA).

Bastagli, F.A. (2008). The design, implementation and impact of conditional cash transfer targeted on the poor: an evaluation of Brazil's bolsa familia. PhD thesis, London school of economics and political science, London.

Beegle, K., Galasso, E., Goldberg, J. (2017). Direct and indirect effects of Malawi's public works program on food security. Journal of Development Economics, 128, 1-23. https://doi.org/10.1016/j.jdeveco.2017.04.004. http://www. sciencedirect.com/science/article/pii/S0304387817300354.

Bianchi, M., \& Bobba, M. (2013). Liquidity, risk, and occupational choices. Review of Economic Studies, 80(2), 491511. https://doi.org/10.1093/restud/rds031. http://oup.prod. sis.lan/restud/article-pdf/80/2/491/18388248/rds031.pdf.

Blanchflower, D.G. (2000). Self-employment in OECD countries. Labour Economics, 7(5), 471-505. https://doi.org/10. 1016/S0927-5371(00)00011-7. http://www.sciencedirect.com/ science/article/pii/S0927537100000117.

Blanchflower, D.G., \& Oswald, A.J. (1998). What makes an entrepreneur? Journal of Labor Economics, 16(1), 26-60. https://doi.org/10.1086/209881.

Blanchflower, D.G., Oswald, A., Stutzer, A. (2001). Latent entrepreneurship across nations. European Economic Review, 45(4-6), 680-691. https://doi.org/10.1016/S00142921(01)00137-4. http://www.sciencedirect.com/science/ article/pii/S0014292101001374. 15th Annual congress of the european economic association.

Blattman, C., Fiala, N., Martinez, S. (2014). Generating skilled self-employment in developing countries: experimental evidence from uganda. Quarterly Journal of Economics, 129(2), 697-752. https://doi.org/10.1093/qje/qjt057.

Bobba, M., \& Gignoux, J. (2019). Neighborhood Effects in Integrated Social Policies. World Bank Economic Review, 33(1), 116-139. https://doi.org/10.1093/wber/lhw061.

Bobonis, G.J., \& Finan, F. (2009). Neighborhood peer effects in secondary school enrollment decisions. Review of Economics and Statistics, 91(4), 695-716. https://doi.org/10. 1162/rest.91.4.695. 
de Brauw, A., Gilligan, D.O., Hoddinott, J., Roy, S. (2015). Bolsa Família and household labor supply. Economic Development and Cultural Change, 63(3), 423-457. https://doi.org/10.1086/680092.

Buera, F.J. (2009). A dynamic model of entrepreneurship with borrowing constraints: theory and evidence. Annals of Finance, 5(3-4), 443-464. https://doi.org/10.1007/s10436009-0121-2.

Chetty, R., Friedman, J.N., Saez, E. (2013). Using differences in knowledge across neighborhoods to uncover the impacts of the EITC on earnings. American Economic Review, 103(7), 2683-2721. https://doi.org/10.1257/aer.103.7.2683. http:// www.aeaweb.org/articles?id=10.1257/aer.103.7.2683.

Crépon, B., Duflo, E., Gurgand, M., Rathelot, R., Zamora, P. (2013). Do labor market policies have displacement effects? Evidence from a clustered randomized experiment. Quarterly Journal of Economics, 128(2), 531580. https://doi.org/10.1093/qje/qjt001. http://oup.prod.sis. lan/qje/article-pdf/128/2/531/17091500/qjt001.pdf.

Crépon, B., Devoto, F., Duflo, E., Parienté, W. (2015). Estimating the impact of microcredit on those who take it up: evidence from a randomized experiment in Morocco. American Economic Journal: Applied Economics, 7(1), 123-50. https://doi.org/10.1257/app.20130535. http://www.aeaweb. org/articles?id=10.1257/app.20130535.

Davies, S., \& Davey, J. (2008). A regional multiplier approach to estimating the impact of cash transfers on the market: the case of cash transfers in Rural Malawi. Development Policy Review, 26(1), 91-111. https://doi.org/10.1111/j.1467-767 9.2008.00400.x.

Duflo, E., \& Saez, E. (2003). The role of information and social interactions in retirement plan decisions: evidence from a randomized experiment. Quarterly Journal of Economics, 118(3), 815-842. https://doi.org/10.1162/00335530360698 432. http://oup.prod.sis.lan/qje/article-pdf/118/3/815/54729 48/118-3-815.pdf.

Evans, D.S., \& Jovanovic, B. (1989). An estimated model of entrepreneurial choice under liquidity constraints. Journal of Political Economy, 97(4), 808-827. https://doi.org/10.1086/261629.

Evans, D.S., \& Leighton, L.S. (1989). Some empirical aspects of entrepreneurship. American Economic Review, 79(3), 519-535. https://doi.org/10.2307/1806861. http:// www.jstor.org/stable/1806861.

Fafchamps, M., \& Gubert, F. (2007). Contingent loan repayment in the Philippines. Economic Development and Cultural Change, 55(4), 633-667. https://doi.org/10.1086/ 516765.

Fafchamps, M., \& Lund, S. (2003). Risk-sharing networks in rural Philippines. Journal of Development Economics, 71(2), 261-287. https://doi.org/10.1016/S0304-3878(03)00 029-4. http://www.sciencedirect.com/science/article/pii/S0 304387803000294.

Fairlie, R.W. (1999). The absence of the African-American owned business: an analysis of the dynamics of selfemployment. Journal of Labor Economics, 17(1), 80-108. https://doi.org/10.1086/209914.

Fairlie, R.W., \& Krashinsky, H.A. (2012). Liquidity constraints, household wealth, and entrepreneurship revisited. Review of Income and Wealth, 58(2), 279-306. https://doi.org/10. 1111/j.1475-4991.2011.00491.x. https://onlinelibrary.wiley. com/doi/abs/10.1111/j.1475-4991.2011.00491.x. https://on linelibrary.wiley.com/doi/pdf/10.1111/j.1475-4991.2011.00 491.x.

Fajnzylber, P., Maloney, W.F., Montes-Rojas, G.V. (2011). Does formality improve micro-firm performance? Evidence from the Brazilian SIMPLES program. Journal of Development Economics, 94(2), 262-276. https://doi.org/10.1016/j.jdeve co.2010.01.009. http://www.sciencedirect.com/science/artic le/pii/S0304387810000118.

Ferro, A.R., Kassouf, A.L., Levison, D. (2010). The impact of conditional cash transfer programs on household work decisions in Brazil. In Polachek, S., \& Tatsiramos, K. (Eds.) Child labor and the transition between school and work, research in labor economics. Emerald group publishing limited, (Vol. 31 pp. 193-218), https://doi.org/10.1108/S01 47-9121(2010)0000031010.

Foguel, M.N., \& Barros, R.P. (2010). The effects of conditional cash transfer programmes on adult labour supply: an empirical analysis using a time-series-cross-section sample of Brazilian municipalities. Estudos Econômicos, 40(2), 259 293. https://doi.org/10.1590/S0101-41612010000200001.

Galor, O., \& Zeira, J. (1993). Income distribution and macroeconomics. Review of Economic Studies, 60(1), 35-52. https://doi.org/10.2307/2297811. http://oup.prod. sis.lan/restud/article-pdf/60/1/35/4480796/60-1-35.pdf.

Gasparini, L., Haimovich, F., Olivieri, S. (2009). Labor informality bias of a poverty-alleviation program in Argentina. Journal of Applied Economics, 12(2), 181-205. https://doi. org/10.1016/S1514-0326(09)60012-X. http://www.science direct.com/science/article/pii/S151403260960012X.

Gertler, P.J., Martinez, S.W., Rubio-Codina, M. (2012). Investing cash transfers to raise long-term living standards. American Economic Journal: Applied Economics, 4(1), 164-192. https://doi.org/10.1257/app.4.1.164. http://www. aeaweb.org/articles?id=10.1257/app.4.1.164.

Ghatak, M., Morelli, M., Sjostrom, T. (2001). Occupational choice and dynamic incentives. Review of Economic Studies, 68(4), 781-810. https://doi.org/10.1111/1467-937X.00 190. http://oup.prod.sis.lan/restud/article-pdf/68/4/781/448 4386/68-4-781.pdf.

Holtz-Eakin, D., \& Rosen, H.S. (2005). Cash constraints and business start-ups: Deutschmarks versus dollars. Contributions to Economic Analysis \& Policy, 4(1), 1-26. https://doi.org/10.2202/1538-0645.1029.

Holtz-Eakin, D., Joulfaian, D., Rosen, H.S. (1994). Entrepreneurial decisions and liquidity constraints. RAND Journal of Economics, 25(2), 334-347. https://doi.org/10. 2307/2555834. http://www.jstor.org/stable/2555834.

Hudgens, M.G., \& Halloran, M.E. (2008). Toward causal inference with interference. Journal of the American Statistical Association, 103(482), 832-842. https://doi.org/10.1198/ 016214508000000292 . pMID: 19081744.

Hurst, E., \& Lusardi, A. (2004). Liquidity constraints, household wealth, and entrepreneurship. Journal of Political Economy, 112(2), 319-347. https://doi.org/10.1086/381 478.

IBGE (2000). Série Relató3rios Metodológicos vol 25, Instituto Brasileiro de Geografia e Estatística, Rio de Janeiro.

Johansson, E. (2000). Self-employment and liquidity constraints: evidence from Finland. Scandinavian Journal of Economics, 102(1), 123-134. https://doi.org/10.1111/1467- 
9442.00187. https://onlinelibrary.wiley.com/doi/pdf/10.111 1/1467-9442.00187.

Karlan, D., \& Zinman, J. (2010). Expanding credit access: using randomized supply decisions to estimate the impacts. Review of Financial Studies, 23(1), 433-464. https://doi.org/ 10.1093/rfs/hhp092. http://oup.prod.sis.lan/rfs/article-pdf/ 23/1/433/24436375/hhp092.pdf.

Kremer, M., \& Miguel, E. (2007). The illusion of sustainability. Quarterly Journal of Economics, 122(3), 1007-1065. https://doi.org/10.1162/qjec.122.3.1007. http://oup.prod.sis. lan/qje/article-pdf/122/3/1007/5312954/122-3-1007.pdf.

La Porta, R., \& Shleifer, A. (2014). Informality and development. Journal of Economic Perspectives, 28(3), 109-26. https://doi.org/10.1257/jep.28.3.109. http://www. aeaweb.org/articles?id=10.1257/jep.28.3.109.

Lalive, R., \& Cattaneo, M.A. (2009). Social interactions and schooling decisions. Review of Economics and Statistics, 91(3), 457-477. https://doi.org/10.1162/rest.91.3.457.

Lindh, T., \& Ohlsson, H. (1996). Self-employment and windfall gains: evidence from the swedish lottery. Economic Journal, 106(439), 1515-1526. https://doi.org/10.2307/22 35198. http://oup.prod.sis.lan/ej/article-pdf/106/439/1515/ 27041753/ej1515.pdf.

Lindh, T., \& Ohlsson, H. (1998). Self-employment and wealth inequality. Review of Income and Wealth, 44(1), 25-42. https: //doi.org/10.1111/j.1475-4991.1998.tb00250.x. https://onli nelibrary.wiley.com/doi/abs/10.1111/j.1475-4991.1998.tb0 0250.x.

Miguel, E., \& Kremer, M. (2004). Worms: identifying impacts on education and health in the presence of treatment externalities. Econometrica, 72(1), 159-217. https://doi.org/10. 1111/j.1468-0262.2004.00481.x.

Monteiro, J.C., \& Assunção, J.J. (2012). Coming out of the shadows? Estimating the impact of bureaucracy simplification and tax cut on formality in Brazilian microenterprises. Journal of Development Economics, 99(1), 105-115. https://doi.org/10.1016/j.jdeveco.2011.10.002. http://www. sciencedirect.com/science/article/pii/S0304387811001052.

Murgai, R., Winters, P., Sadoulet, E., de Janvry, A. (2002). Localized and incomplete mutual insurance. Journal of Development Economics, 67(2), 245-274. https://doi.org/ 10.1016/S0304-3878(01)00189-4. http://www.sciencedirec t.com/science/article/pii/S0304387801001894.

Nykvist, J. (2008). Entrepreneurship and liquidity constraints: evidence from Sweden. Scandinavian Journal of Economics, 110(1), 23-43. https://doi.org/10.1111/j.1467-944 2.2008.00523.x. https://onlinelibrary.wiley.com/doi/pdf/10. 1111/j.1467-9442.2008.00523.x.

Oliveira, A.M.H., Andrade, M.V., Resende, A.C.C., Rodrigues, C.G., Souza, L.R., Ribas, R.P. (2007). First results of a preliminary evaluation of the Bolsa família program. In Vaitsman, J., \& Paes-Sousa, R. (Eds.) Evaluation of
MDS policies and programs - results, (Vol. 2 pp. 19-64). Brasília: MDS.

Persson, P., \& Lee, S. (2016). Financing from family and friends. Review of Financial Studies, 29(9), 2341-2386. https://doi.org/10.1093/rfs/hhw031. http://oup.prod.sis.lan/ rfs/article-pdf/29/9/2341/24440645/hhw031.pdf.

Rosenzweig, M.R., \& Wolpin, K.I. (1993). Credit market constraints, consumption smoothing, and the accumulation of durable production assets in low-income countries: investments in bullocks in India. Journal of Political Economy, 101(2), 223-244. https://doi.org/10.1086/261874.

Sadoulet, E., de Janvry, A., Davis, B. (2001). Cash transfer programs with income multipliers: PROCAMPO in Mexico. World Development, 29(6), 1043-1056. https://doi.org/10. 1016/S0305-750X(01)00018-3. http://www.sciencedirect. com/science/article/pii/S0305750X01000183.

Saez, E. (2010). Do taxpayers bunch at kink points? American Economic Journal: Economic Policy, 2(3), 180-212. https: //doi.org/10.1257/pol.2.3.180. http://www.aeaweb.org/artic les?id=10.1257/pol.2.3.180.

Schechter, L., \& Yuskavage, A. (2012). Inequality, reciprocity, and credit in social networks. American Journal of Agricultural Economics, 94(2), 402-410. https://doi.org/10.1093/ ajae/aar109. http://oup.prod.sis.lan/ajae/article-pdf/94/2/40 2/128136/aar109.pdf.

Tavares, P.dA. (2008). O efeito do programa Bolsa Família sobre a oferta de trabalho das mães. In Proceedings of the 36th Brazilian Economics Meeting: ANPEC.

Taylor, M.P. (2001). Self-employment and windfall gains in britain: evidence from panel data. Economica, 68(272), 539-565. https://doi.org/10.1111/1468-0335.00261. https:// onlinelibrary.wiley.com/doi/abs/10.1111/1468-0335.00261.

Teixeira, C.G. (2010). Heterogeneity analysis of the bolsa família programme effect on men and women's work supply. Working paper 61, international policy centre for inclusive growth (IPC-IG).

Tsai, K.S. (2004). Imperfect substitutes: the local political economy of informal finance and microfinance in rural China and India. World Development, 32(9), 1487-1507. https:// doi.org/10.1016/j.worlddev.2004.06.001. http://www.scien ce/article/pii/S0305750X04000956.

Zissimopoulos, J.M., \& Karoly, L.A. (2007). Transitions to self-employment at older ages: the role of wealth, health, health insurance and other factors. Labour Economics, 14(2), 269-295. https://doi.org/10.1016/j.labeco.2005.08. 002. http://www.sciencedirect.com/science/article/pii/S092 7537105000552 .

Publisher's note Springer Nature remains neutral with regard to jurisdictional claims in published maps and institutional affiliations. 